\title{
Influence of microclimate and geomorphological factors on alpine vegetation in the Western Swiss Alps
}

\author{
Elisa Giaccone, ${ }^{1 *}$ (D) Miska Luoto, ${ }^{2}$ (D) Pascal Vittoz, ${ }^{1}$ (D) Antoine Guisan, ${ }^{1,3}$ (D) Grégoire Mariéthoz ${ }^{1}$ (DD and \\ Christophe Lambiel ${ }^{1}$ (iD \\ ${ }^{1}$ Institute of Earth Surface Dynamics, University of Lausanne, Lausanne, Switzerland \\ 2 Department of Geosciences and Geography, University of Helsinki, Helsinki, Finland \\ 3 Department of Ecology and Evolution, University of Lausanne, Lausanne, Switzerland
}

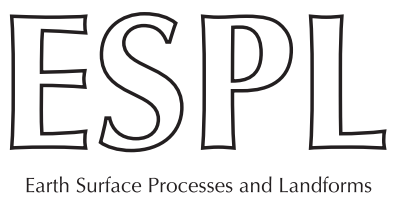

ABSTRACT: Among the numerous environmental factors affecting plant communities in alpine ecosystems, the influence of geomorphic processes and landforms has been minimally investigated. Subjected to persistent climate warming, it is vital to understand how these factors affect vegetation properties. Here, we studied 72 vegetation plots across three sites located in the Western Swiss Alps, characterized by high geomorphological variability and plant diversity. For each plot, vascular plant species were inventoried and ground surface temperature, soil moisture, topographic variables, earth surface processes (ESPs) and landform morphodynamics were assessed. The relationships between plant communities and environmental variables were analysed using non-metric multidimensional scaling (NMDS) and multivariate regression techniques (generalized linear model, GLM, and generalized additive model, GAM). Landform morphodynamics, growing degree days (sum of degree days above $5^{\circ} \mathrm{C}$ ) and mean ground surface temperature were the most important explanatory variables of plant community composition. Furthermore, the regression models for species cover and species richness were significantly improved by adding a morphodynamics variable. This study provides complementary support that landform morphodynamics is a key factor, combined with growing degree days, to explain alpine plant distribution and community composition. (C) 2019 John Wiley \& Sons, Ltd.

KEYWORDS: alpine environment; geomorphology; earth surface processes; vegetation community

\section{Introduction}

Understanding the impacts of climate change on earth surface processes and biota is a key challenge for both geomorphological and ecological studies. This is particularly important for alpine environments, where geomorphological processes drive landscape evolution and ecosystem dynamics subjected to climate change (Haeberli and Beniston, 1998; Gobiet et al., 2014). During the last century, the minimum air temperatures increased by as much as to $2^{\circ} \mathrm{C}$ in these systems, whereas the maximum temperatures exhibited a more modest but measurable rise (Beniston, 2005; Acquaotta et al., 2015). This warming was twice the average temperature change in the Northern Hemisphere, causing an acceleration of snow and ice melt, an upshift of the snowline and changes in water resources availability (Auer et al., 2007; Beniston et al., 2018).

Alpine ecosystems, and especially vegetation, are impacted by ongoing climate change (Füssel et al., 2017). The upward shift of plants is observed in many studies in Europe (Dullinger et al., 2012; Gottfried et al., 2012; Steinbauer et al., 2018).
Furthermore, following glacial retreats, new surfaces are exposed to atmospheric conditions. Within a few years, paraglacial adjustments rework the sediments (Ballantyne, 2002) and vegetation begins to colonize the free environments (Matthews, 1992). Primary plant succession is proven to be predominantly driven by time since deglaciation, soil grain size and water content (Burga et al., 2010), but other complex factors such as snowmelt, topography and disturbance also control vegetation development (Matthews and Whittaker, 1987; Anderson et al., 2000).

Several studies have demonstrated the importance of geomorphic processes on alpine ecosystems. Investigations on the effects of earth surface processes (ESPs) on alpine vegetation offer evidence that plant communities are affected by physical disturbances related to geomorphological processes (Gentili et al., 2013; le Roux and Luoto, 2014; Virtanen et al., 2010). The latter can modify microhabitat conditions and therefore control species richness, composition and distribution patterns of plant communities (Vonlanthen et al., 2006a; le Roux et al., 2013). In addition, geomorphic 
processes not only disturb plant communities, but they are also important dispersal vectors (e.g., Gentili et al., 2010) and promote the colonization of plant species adapted to the disturbance (Corenblit et al., 2011).

Several authors have investigated the linkage between vegetation and geomorphic dynamics in alpine environments. In the permafrost-affected areas, and more broadly in the periglacial domain, vegetation exhibits different patterns between active rock glaciers (low vascular plant cover) and inactive-relict rock glaciers (high cover - Burga et al., 2004; Cannone \& Gerdol, 2003), even if quality of substrate, surface deformation and microtopography remain critical factors for plant distribution (Burga et al., 2004; Colombo et al., 2016). This was also demonstrated for frost-related landforms, such as polygonal soils, where only particular plant compositions exist (Béguin et al., 2009). However, in the Alps, permanently frozen ground has rarely a direct interference with plant growth because of the thickness of the surficial layer above permafrost which thaws during summer (called "active layer" - Körner, 2003; van Tatenhove and Dikau, 1990). The latter has for instance values around 3 to $5 \mathrm{~m}$ depth in the Swiss Alps (PERMOS, 2019). Besides, arctic-alpine communities exhibit strong responses to different ESPs, such as cryoturbation, deflation, fluvial processes, nivation and solifluction (le Roux and Luoto, 2014), and they are also influenced by other geomorphological processes such as rock/debris falls, debris flow, avalanches and running water (Gentili et al., 2013). Furthermore, in addition to water, nutrients availability and the microclimate, plant colonization also depends on surface stability (Baroni et al., 2007; Gentili et al., 2010; Baroni et al., 2013). Such a two-way linkage was confirmed by other authors studying the interactions between subalpine alluvial fans and floristic diversity (Lane et al., 2016) and between sediment reworking on a lateral Little Ice Age (LIA) moraine and bioengineering species (Eichel et al., 2016; Eichel et al., 2017).

While the relationships between plant composition and soil-topo-climatic variables have been yet highlighted at high resolution especially on lowland and montane regions (e.g. Dubuis et al., 2013; Pradervand et al., 2014), more specific aspects of the plant-geomorphic processes relationships remained unclear, in particular at high elevations. This would allow answering questions such as: how do ESPs influence plant communities? How do geomorphological heterogeneity and landform morphodynamics affect vegetation distribution? Among the geomorphic processes, which types control alpine community composition? Moreover, in the context of climate change, which mechanisms operate between alpine plant distribution and landform stabilization (Virtanen et al., 2010; Alatalo et al., 2016; Eichel et al., 2017)? In the present study, the term ESP indicates different processes that involve the ground surface. With landform morphodynamics, however, we refer to the entire processes that can occur on a specific landform, including the possible movement of the landform itself. For geomorphological heterogeneity, we refer to the variability of landforms in a catchment.

The objective of this study is to understand the joint influence of geomorphology, topography and microclimatology on alpine vegetation. More specifically, we aim to assess how landform morphodynamics, ESPs (solifluction, rill erosion, nivation and frost weathering), topography (elevation, slope, aspect) and other environmental variables such as ground temperature and soil moisture drive alpine plant distribution, species richness and community composition. The study was conducted in three high-elevation sites in the Western Swiss Alps, characterized by different age deposits and high geomorphological variability and biodiversity. Based on the theory and findings reported previously (and elsewhere, e.g., in Körner, 2003; Ozenda, 1985), we expect microtopography, microclimate, snow cover, soil moisture and ESPs to be among the most important explanatory factors of community composition and species richness.

\section{Material and methods}

\section{Study area}

Our study area is located in the Vaud Alps (Western Swiss Alps). All three sites are situated in or near the Vallon de Nant $\left(46^{\circ} 13^{\prime} 44^{\prime \prime} \mathrm{N}, 7^{\circ} 05^{\prime} 59^{\prime \prime} \mathrm{E}\right)$, a tight valley surrounded by high rock walls (max. elevation 3051 ma.s.I.) and oriented SW$\mathrm{NE}$, which has been extensively studied in geomorphological and biological fields (e.g., Lambiel et al., 2009; Vittoz and Gmür, 2009; Lane et al., 2016; Thornton et al., 2018).

Due to its location on the northwest side of the Alps and because most of the climatic perturbations come from the west, the region receives abundant annual precipitation $(1800 \mathrm{~mm} /$ $y$ in Pont de Nant, 1253 ma.s.l.) and winter snow-fall. The mean annual temperatures are $7^{\circ} \mathrm{C}$ in Pont de Nant and $-3^{\circ} \mathrm{C}$ on the summits. This cold and wet climate, associated with the shadow of the high rock walls, supports the presence of small glaciers (Les Martinets and Plan Névé glaciers).

Geologically, the region is located on the inverse flank of the Morcles nappe and it consists primarily of limestone and some siliceous rocks deposited between the Middle Jurassic and the Eocene (Badoux, 1991). The geomorphological diversity of the region is high, with various landforms, such as Holocene moraines, rock glaciers and talus slopes. According to the Alpine Permafrost Index Map (Boeckli et al., 2012) and geomorphological interpretation (Lambiel et al., 2009; Perret \& Martin, 2015), permafrost is expected to be present above $2400 \mathrm{~m}$ a.s.l. in the north-exposed slopes.

Three focus sites situated at elevations ranging between 1950 and $2550 \mathrm{~m}$ a.s.l. were selected based on geomorphological variability and biodiversity: Les Martinets, Col des Perris Blancs and Les Outans (Figure 1). The landscape of Les Martinets (Figure 1B and D) is dominated by the Glacier des Martinets (ca. 2200-2680 ma.s.l.), with its numerous moraines dating back to the LIA and to older Holocene or Late Glacial periods. A large and thick rock glacier is located on the western part of the catchment, at elevations between 2240 and 2440 ma.s.l. This rock glacier consists of two different lobes corresponding to two different generations. Orthoimage analyses suggest very low activity for the upper lobe, whereas the lower one seems to be inactive. The geomorphological characteristics (steep front, bulging surface) suggest the presence of permafrost conditions in the rock glacier despite the relatively low elevation (Lambiel et al., 2009). It was confirmed by an electrical resistivity tomography profile (Giaccone, Mariéthoz, \& Lambiel, 2016 - see Supplementary material Figure S1). Finally, talus slopes crossed by several debris flow channels and a large area of rock fall/avalanche deposits are present on the northwest side.

The Col des Perris Blancs site (Figure 1B and E) is located on the northwest side of the Martinets catchment, at elevations between 2400 and $2544 \mathrm{~m}$ a.s.l. It corresponds to a north-exposed slope, with outcrops generating frost weathering deposits and some areas covered by alpine grasslands. The high quantity of debris derived from outcrops formed a debris slope with small lobes, which suggests frost creep, and originated a protalus rampart. 

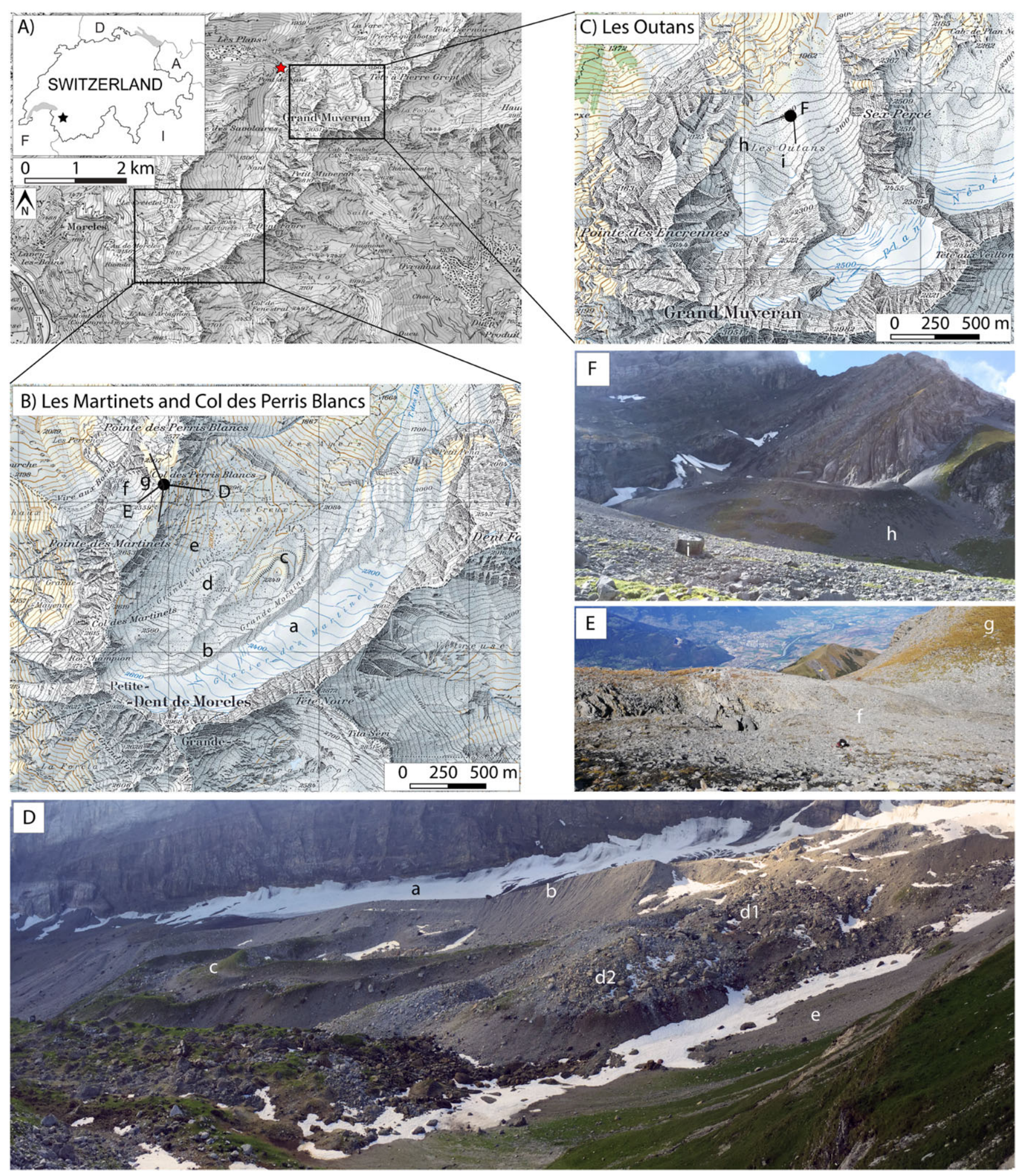

Figure 1. A) Locations of the three selected sites. The red star indicates the location of Pont de Nant (1253 m a.s.I.) B) Topographic map of Les Martinets and Col des Perris Blancs. C) Topographic map of Les Outans. D) Detailed picture of Les Martinets, seen from the Col des Perris Blancs (August 2016); a: The Glacier des Martinets; b: LIA moraine; c: Holocene moraines; d1 : rock glacier, upper lobe; d2: rock glacier, lower lobe; e: talus slope. E) Detailed picture of Col des Perris Blancs, seen from the namesake alpine pass (September 2018); f: debris slope; g: alpine grassland. F) Detailed picture of Les Outans; h: steep latero-frontal moraines of the debris-covered glacier; i: debris slope (September 2018). SwissMapRaster (C) swisstopo (DV084371). [Colour figure can be viewed at wileyonlinelibrary.com]

Les Outans site (Figure $1 \mathrm{C}$ and $\mathrm{F}$ ) is characterized by steep slopes exposed to the north, with elevations between ca. 1950 and $2300 \mathrm{~m}$ a.s.I. The main landforms are LIA moraines created by the Glacier de Plan Névé, located in the southeast section (ca. 2400-2680 m a.s.I.), and, in the western part, an unnamed small debris-covered glacier that erected voluminous moraines (ca. 2100-2300 ma.s.l.). The remaining surface is constituted by an extended debris slope made of gravitative (talus slope) and torrential deposits.

The vegetation in Vallon de Nant was studied by Dutoit (1983) and summarized in Vittoz and Gmür (2009) and Vittoz et al. (2009). Beech, fir and spruce forests (Abieti-Fagenion according to Delarze et al., 2015) dominate the lowest part of the region (1200-1400 ma.s.I.), replaced locally by pasturelands 
(Cynosurion) grazed by cows in summer. Spruce and larch forests (Vaccinio-Piceion) dominate the subalpine belt (14001900 ma.s.l.), replaced by maple forests (Lunario-Acerion) on steep, unstable slopes, green alder bushes (Alnenion viridis) on avalanche paths, pasturelands (Poion alpinae, Nardion) on the flat, exploited areas and heathlands (RhododendronVaccinion) when grazing is abandoned. The alpine belt (1900-2800 ma.s.l.) is a mixture of calcareous alpine grasslands (Seslerion, Caricion ferrugineae, Arabidion caeruleae) and rocky areas (moraines, rock glaciers, cliffs). The subalpine and alpine belts are severely intersected by long talus slopes and alluvial/colluvial fans colonized by communities of the Thlaspion rotundifolii, Epilobion fleischeri or Petasition paradoxi according to the dynamics, stone size and humidity.

\section{Vegetation plot surveys}

During the summers of 2016 and 2017, vegetation surveys were conducted in 72 plots of $2 \times 2 \mathrm{~m}$ each, scattered in the three study sites. The innovative aspect of our study was that the location of the plots, selected in an ad-hoc stratified way before fieldwork in order to ensure that samples represented each geomorphological feature (e.g., LIA and pre-LIA moraines, talus slope, rock glacier, rock fall/avalanche deposit, debris-covered glacier, glacial surface accumulation, periglacial deposit) with all types of vegetation cover, from pioneer plants with low percentage cover on debris to stable grasslands with high cover. The topographical information and type of landforms for each plot are reported in Supplementary material Table S1, along with species cover and species richness. Each vascular plant species in the plot was listed (nomenclature following Lauber et al., 2012) and a cover-abundance value was assigned to every species (Table I), in accordance to the Braun-Blanquet scale (Braun-Blanquet, 1932). The total vascular plant cover (here species cover) was estimated in the field. The central point of each plot was registered by GNSS (using

Table I. Braun-Blanquet scale (Braun-Blanquet, 1932) and its transformations used in the analyses

\begin{tabular}{llll}
\hline $\begin{array}{l}\text { Range of species } \\
\text { cover (\%) }\end{array}$ & $\begin{array}{l}\text { Braun-Blanquet } \\
\text { scale }\end{array}$ & $\begin{array}{c}\text { Mean cover } \\
\text { (mod. from } \\
\text { Wildi 2013) }\end{array}$ & $\begin{array}{l}\text { Numerical } \\
\text { dominance }\end{array}$ \\
\hline Absent & Absent & 0 & 0 \\
$1-2$ individuals & $r$ & 0.05 & 0.1 \\
$<5$, few individuals & + & 0.5 & 0.5 \\
$<5$ & 1 & 3 & 1 \\
$5-25$ & 2 & 15 & 2 \\
$25-50$ & 3 & 37.5 & 3 \\
$50-75$ & 4 & 62.5 & 4 \\
$75-100$ & 5 & 87.5 & 5 \\
\hline
\end{tabular}

a Garmin Montana® 610). For each survey, species richness (number of species per plot) and evenness (biodiversity index measuring the dominance of one species above the others in the same survey) were calculated to characterize the biodiversity within the plots.

For each vegetation plot, a morphodynamics index, ranging from 0 to 9 , was defined according to the landform morphodynamics: 0 corresponds to a plot location on a stable landform and 9 on a landform affected by high activity. The details for the attribution of each value are given in Table II. The index is composed of three criteria: frequency of disturbances that affect the deposit (i.e., debris flow, avalanche), movement of the surface and soil development. For each criterion, a value ranging from 0 and 4 is assigned based on intensity of phenomenon and then summed to obtain the final index for each plot. This index is adapted from the methodology reported in Randin et al. (2009). The frequency of disturbances and the surface movement were evaluated using orthophotos of the study area from 1980 to 2016, obtained from the Swiss Office of Topography (https://map.geo.admin.ch), and through geomorphological interpretation; soil development was evaluated in the field.

To define the type of external disturbance in each site, the presence of the four selected ESPs - solifluction, rill erosion, nivation and frost weathering - were reported using a value from 0 to 4 to inform on the intensity of the phenomenon (0: phenomenon absent, 4 : phenomenon very intense), following the methodology reported in Gentili et al. (2013). If no ESP evidence was found, the plot was assigned to the "No ESP" category. To limit any potential human bias, the same observer performed all surveys.

Furthermore, in September 2018, after a particularly dry period, soil moisture was measured as volumetric water content (VWC \%) with a hand-held reflectometry sensor (FieldScout, TDR150; Spectrum Technologies). Short rods $(3.8 \mathrm{~cm})$ were adopted. For each plot, 5 measurements at 5 points (corners and centre), for a total of 25 measurements, were averaged (Kemppinen et al., 2018). However, for most of the plots it was impossible to measure the soil moisture due to the extremely low proportion of fine soil material. Therefore, as an alternative, we used the triangle method of Sandholt et al. (2002) to compute the temperature vegetation dryness index as:

$$
\mathrm{TVDI}=(\mathrm{Ts}-\mathrm{Tsmin}) /[(\mathrm{a}+\mathrm{b} * N D V I)-\mathrm{Tsmin}]
$$

where $T_{s}$ is the observed surface temperature at a given pixel, Tsmin is the minimum surface temperature, $a$ and $b$ are parameters defining the dry edge modelled as a linear fit to the data and $N D V I$ is the observed normalized difference vegetation index. The term $a+b^{*} N D V I$, also known as Tsmax, is the maximum surface temperature observation for a given NDVI. To measure the temperature, iButton temperature data were employed (see following section). Considering the high soil

Table II. Guidelines to assign the morphodynamics index to each plot (based on Randin et al., 2009)

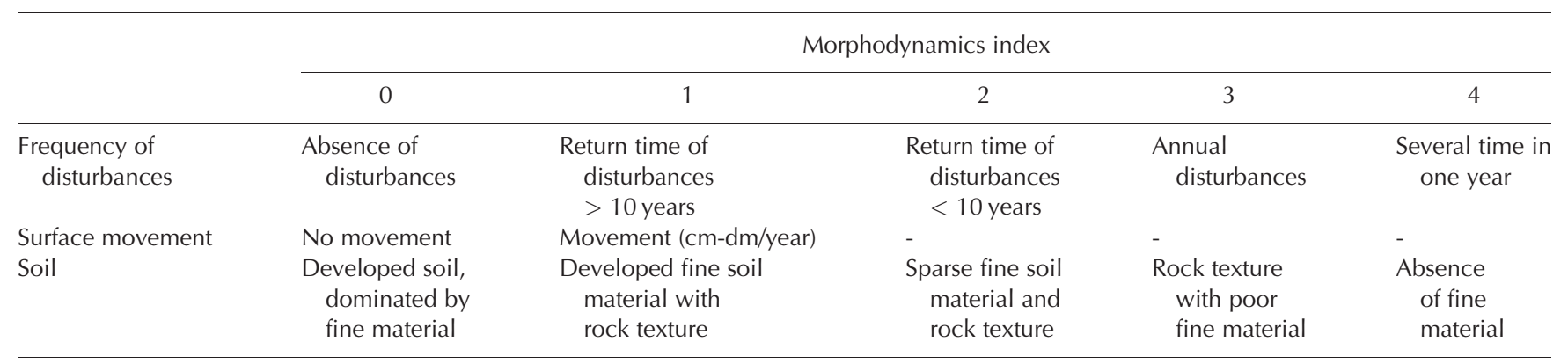


moisture variability, Tsmin and Tsmax were, respectively, the minimum and maximum daily temperatures recorded during July and August 2017 between all the iButtons and $T s$ the mean daily temperatures of the same months. NDVI was calculated at a resolution of $25 \mathrm{~cm}$, using the infrared and red bands of the false-color infrared orthophoto mosaic obtained from the Swiss Office of Topography for the year 2013. Then the value corresponding to the plot center was selected for the calculation.

Finally, topographic variables (elevation, orientation, slope angle) were computed for each plot location, based on the SwissAlti3D DEM (resolution grid $2 \mathrm{~m}$, Swiss Office of Topography).

\section{Ground surface temperature monitoring}

To investigate the microclimate of the ground surface, snow duration and occurrence of permafrost at each vegetation plot, continuous monitoring of the ground surface temperature (GST) was performed using iButton® DS1922L miniature temperature loggers (accuracy $\pm 0.5^{\circ} \mathrm{C}$, resolution $0.0625^{\circ} \mathrm{C}-$ Gubler et al., 2011; Ishikawa, 2003). In total, 72 loggers were buried at $5 \mathrm{~cm}$ depth from 1 of October 2016 to 30 September 2018 with a measurement interval of 3 hours. Because the iButtons are not entirely impermeable, they were placed inside small waterproof containers sealed with tape.

To study the ground thermal regime, different temperature indices were calculated based on the two-year data average:

i Mean ground surface temperature (MGST), minimum (Tmin) and maximum (Tmax) temperatures;

ii Basal-ripening date (RD): time when a frozen ground surface is warmed to $0^{\circ} \mathrm{C}$ by percolating melt-water or by strong rain-on-snow events (Westermann et al., 2011; Schmid et al., 2012);

iii Melt-out date (MD): time when the snow cover is completely melted and thus when the ground can warm above $0^{\circ} \mathrm{C}$ (Schmid et al., 2012);

iv Freezing degree day (FDD): sum of degree days below $0^{\circ} \mathrm{C}$;

$\checkmark$ Growing degree day (GDD): sum of degree days above $5^{\circ} \mathrm{C}$ (Scherrer and Körner, 2011);

vi Growing season length (GSL): number of days between MD and the first day of September with ground temperatures below $3.2^{\circ} \mathrm{C}$ (Körner and Paulsen, 2004).

In addition, the bottom temperature of the winter snow cover (BTS) method was employed to define the areas where permafrost is possible (Haeberli, 1973; Hoelzle et al., 1993; Ikeda and Matsuoka, 2002; Lambiel and Pieracci, 2008). The method is based on the fact that heat exchanges between atmosphere and ground surface are strongly reduced during late winter below a snow cover thicker than $\sim 80 \mathrm{~cm}$, which maintains stable temperatures (Staub et al., 2015). Therefore, the temperature measured at the snow/ground interface reflect the ground thermal state and can be used as an indirect indicator of permafrost conditions (Hoelzle et al., 1999; Ishikawa, 2003). Temperature below $-2{ }^{\circ} \mathrm{C}$ during late winter are usually considered as an indicator for the possible presence of permafrost (Haeberli, 1973; Ishikawa, 2003).

\section{Statistical analysis}

All statistical analyses and models were conducted using $\mathrm{R} v$. 3.2.3 (R Development Core Team, 2015).

Spearman's rank correlation coefficient was performed to assess the relationship between species cover, species richness and evenness variables. A Mantel's test (Mantel, 1967) was achieved with the mantel.rtest function of the ade4 package (v. 1.7-13) to test for spatial autocorrelation in the species cover and species richness variables across plots. Null hypothesis affirmed that matrices were not correlated.

The plant covers determined using the Braun-Blanquet scale were transformed according to the mean cover of Wildi (2017) for subsequent analyses (see Table I). The Bray-Curtis dissimilarity index (Bray and Curtis, 1957) was calculated between plots. The resulting dissimilarity matrix was employed as an input for a non-metric multi-dimensional scaling (NMDS) ordination method, performed with the metaMDS function of the vegan package (v. 2.4-0) and which visualizes plots according to their floristic similarities (Oksanen et al., 2007). NMDS allows the ordering relationships among objects in two main axes to be represented, using rank orders and minimizing the ordination stress (i.e., disagreement between the 2D configuration and similarity matrix) with multiple iterations. Two dimensions were calculated for NMDS. Then, we incorporated the environmental factors (MGST, maximum temperature, minimum temperature, FDD, GDD, GSL, elevation, aspect, slope, morphodynamics, TVDI, solifluction, rill erosion, nivation and frost weathering) into the NMDS analysis with the envfit function using a permutation approach (999 permutations), to test the relations between the ordered plant communities and environmental factors. The linear fit for each variable along the NMDS axis was determined and its significance tested. Nonparametric smoothed surfaces were calculated for each environmental factor and reproduced on the ordination plot by using the ordisurf function to investigate the non-linearity of the relationships.

Cluster analysis was also performed to classify the plots according to their floristic similarity. For this analysis, individual species cover was transformed following the numerical dominance reported in Table I. The Bray-Curtis dissimilarity index was used to build the dendrogram using the hclust function (Ward's method) of the stats package. Based on fieldwork observations, five groups were retained to classify the plant communities and the mean temperature and environmental factor values were specified for each.

The influence of predictor variables on species cover and species richness was examined using generalized linear models (GLMs) and generalized additive models (GAMs) as applied in previous studies (e.g., le Roux and Luoto, 2014). GLMs and GAMs are generalized regression methods. A GAM is a semiparametric equivalent of parametric GLM that uses smoothers to estimate the relationship between predictor and response variables (Yee and Mitchell, 1991; Guisan et al., 2002; Franklin, 2010). More specifically, GLMs and GAMs were used to examine the relationships between response variables (species cover and species richness) and baseline explanatory variables (elevation, slope, aspect, MGST, Tmax, Tmin, FDD, GDD, GSL, TVDI). Then, environmental factors (morphodynamics index and ESPs) were added to the baseline model to test their additional effect in an advanced model. The Spearman correlation coefficient was set to $|\rho|>0.7$ as criterion to limit collinearity between the explanatory variables (Dormann et al., 2013). For pairs of variables with correlation above this threshold, we selected the one with the highest value of correlation in the NMDS analysis. GLMs were fitted using the stats package. An ANOVA F-test was applied to analyse the variance. To model species cover, four types of models were tested to identify the most appropriate setting. The first trial included linear terms of explanatory variables and the family argument "quasipoisson"; the second included quadratic terms of the explanatory variables and the "quasipoisson" family; the third included linear terms and the "quasibinomial" family; and the final trial included quadratic terms and the "quasibinomial" 
family. When the family argument "quasibinomial" was used, species cover values were transformed to a proportion scale $(0-1)$. To model species richness, the family argument was defined as "quasipoisson" due to over-dispersion in the data (Crawley, 2007). GAMs were fitted using the mgcv package (v. 1.8.22). The family was defined as "quasipoisson" for the same reason as for GLMs. The initial degree of smoothness was set to 3 for each variable (Wood, 2017). Once again, we first developed a baseline model and then added the additional environmental factors tested in this study.

\section{Results}

\section{Plant communities}

The location of the plots is illustrated in the next section (Figure 2). The identified communities belong to the alliances described in Table III (Delarze et al., 2015).

In total, 128 species were identified. In plot $\mathrm{n}^{\circ} 11$ no species was present. A large portion of plots was unaffected by ESPs (27 plots). Rill erosion affected mainly 21 plots, frost weathering 11, nivation 7 and solifluction 5, but most of the plots were affected by more than one ESP. Values of species cover and species richness were lower in the plots characterized by ESPs, compared to the category "No ESP". Instead, values of evenness were higher. Details are provided in Table IV. Equally, plots characterized by high morphodynamics index presented lower species cover and species richness.

Species cover differed strongly between debris plots (0-40 \%) and grassland plots (75-100\%). Species richness increased progressively but not linearly from debris locations (minimum 0 species in plot $\mathrm{n}^{\circ} 11$, Les Martinets) to grasslands (maximum 26 species in plot $n^{\circ} 6$, Les Martinets). In some cases, microtopographic factors induced a higher species richness in
Table III. Alliances (Delarze et al., 2015) to which the plots belong and their characteristics

\begin{tabular}{|c|c|}
\hline Alliance name & Characteristics \\
\hline Thlaspion rotundifolii & calcareous screes of alpine belt \\
\hline Drabion hoppeanae & calcschist screes of alpine belt \\
\hline Petasition paradoxi & wet calcareous screes \\
\hline Androsacion alpinae & siliceous screes of alpine belt \\
\hline Elynion & grasslands on windy ridge \\
\hline Seslerion & dry calcareous grasslands \\
\hline Caricion firmae & rocky calcareous grasslands of alpine belt \\
\hline Caricion curvulae & acidophilous grasslands of alpine belt \\
\hline Poion alpinae & pastures of the subalpine and lower alpine belts \\
\hline Arabidion caeruleae & calcareous snow beds \\
\hline Salicion herbaceae & acidophilous snow beds \\
\hline Rhododendro- & \\
\hline Vaccinion & subalpine heaths on acidic soil \\
\hline
\end{tabular}

debris areas (e.g., 20 species in plot $n^{\circ} 16$ located on the lower lobe of the Martinets rock glacier). The mean evenness was low $(<0.5)$, indicating a general prevalence of a low number of species (see Supplementary material Figure S2 for images).

Species cover and species richness were highly correlated (Spearman's correlation $\rho=0.82$ ). Evenness was negatively correlated with both species cover $(\rho=-0.78)$ and species richness $(\rho=-0.71)$. The Mantel test revealed no spatial autocorrelation in the two response variables (species cover and species richness).

According to the clustering of the 71 plant surveys in five groups (the empty plot is not considered here-Figure 4), the first group comprised pre-LIA sites, characterized by latesuccessional species belonging to Poion alpinae, Rhododendro-Vaccinion, Elynion, Seslerion, Caricion firmae and Caricion curvulae (according to Delarze et al., 2015). In the second group, debris plots with Salix sp. (snowbeds of

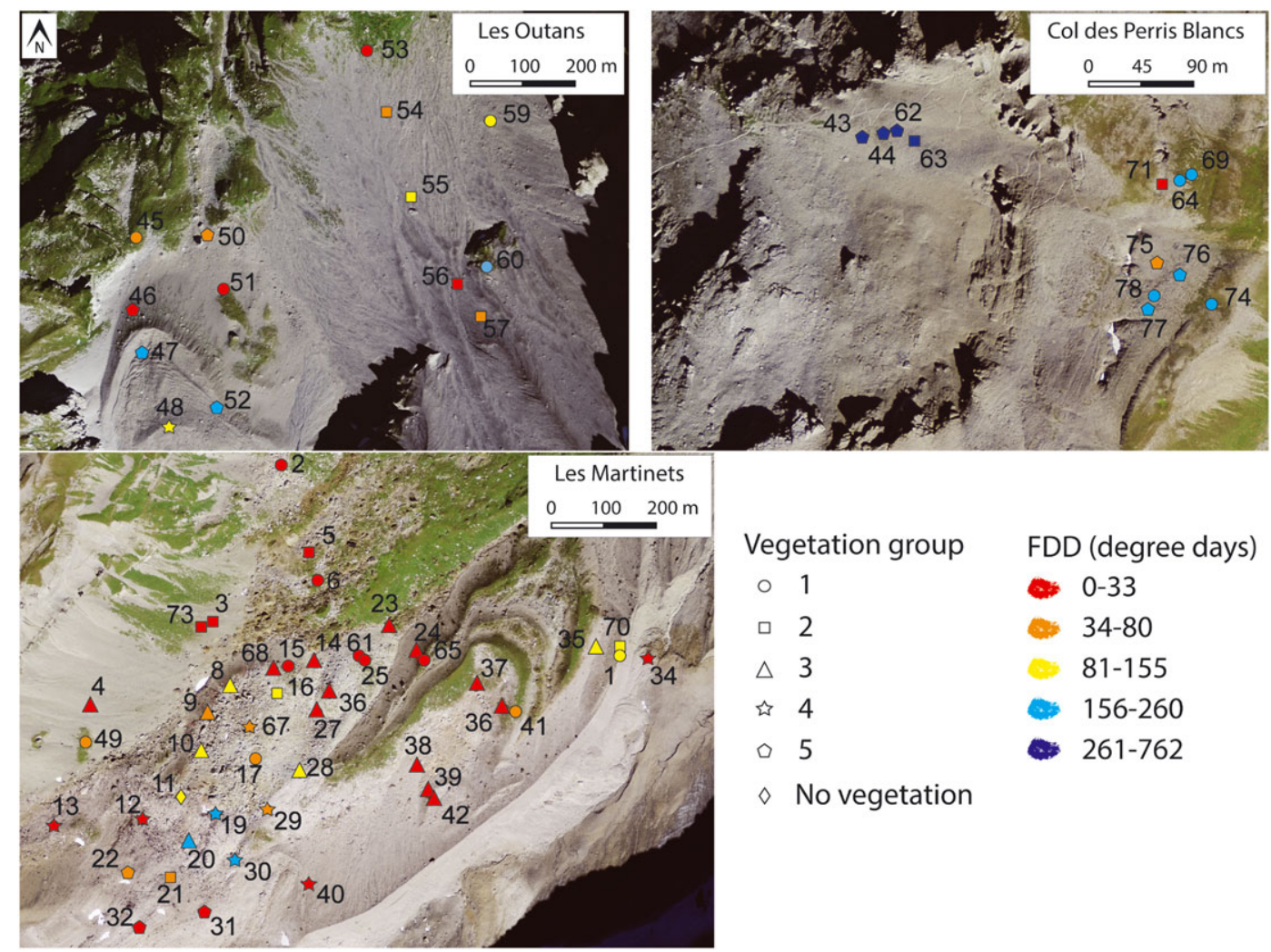

Figure 2. Location of vegetation plots, grouped based on cluster analysis. Colors indicate the value of the Freezing degree days index (01.10.201630.09.2018) for Les Outans, Col des Perris Blancs and Les Martinets. Swisslmage @ c swisstopo (DV084371). [Colour figure can be viewed at wileyonlinelibrary.com] 
Table IV. Number of plots and community characteristics observed in the different ESP categories (absence of ESP, solifluction, rill erosion, nivation and frost weathering). Mean values and standard deviation are reported. Species cover: percentage of vascular plant cover [\%]. Species richness: number of species per plot. Evenness: biodiversity index measuring the dominance of one species above the others in the same survey

\begin{tabular}{llllr}
\hline ESPs & Number of plots & Sp. cover & Sp. richness & \multicolumn{1}{c}{ Evenness } \\
\hline No ESP & 27 & $52 \pm 38$ & $15 \pm 5$ & $0.31 \pm 0.13$ \\
Solifluction & 5 & $11 \pm 4$ & $8 \pm 7$ & $0.44 \pm 0.19$ \\
Rill erosion & 21 & $25 \pm 23$ & $11 \pm 4$ & $0.43 \pm 0.19$ \\
Nivation & 7 & $20 \pm 20$ & $11 \pm 5$ & $0.45 \pm 0.15$ \\
Frost weathering & 11 & $31 \pm 24$ & $12 \pm 4$ & $0.48 \pm 0.21$ \\
\hline
\end{tabular}

Arabidion caeruleae or Salicion herbaceae) and the debris characterized by high water availability (due to percolation or late melting of snow patches - named hereafter "wet debris"; Petasidion paradoxi) were grouped. The plots located on the older debris belonging to pre-LIA periods (Thlaspion rotundifolii and Drabion hoppeanae, with some species belonging to Cystopteridion and Potentillion - shady and sunny calcareous cliffs with vascular vegetation) were found in the third cluster. In contrast, vegetation on moraines and dynamics debris more recent than LIA (Thlaspion rotundifolii, Drabion hoppeanae) constituted the fourth group. Plots in the last group were characterized by species adapted to low temperatures; thus, the plots belonged to Androsacion alpinae and Thlaspion rotundifolii. The ecological and environmental characteristics of the five groups are reported in Table $\mathrm{V}$.

The pre-LIA moraines, as well as the surfaces not covered by ice during the LIA and those not affected by ESPs, were colonized by late successional stage species (plots of group 1). In Les Outans, grasslands were only present in the lower elevation areas (1960-2030 ma.s.I.) or on bedrock outcrops. The wet calcareous screes as well as the debris-covered glacier were colonized by pioneer species belonging to Petasition paradoxi, Thlaspion rotundifolii and Drabion hoppeanae (groups 2, 4 and 5). In the Col des Perris Blancs, acidophilous species such as Ranunculus glacialis (Androsacion alpinae) were identified next to basiphilous species belonging to Thlaspion rotundifolii (group 5). Pioneer species were present in the front of the creeping lobes (Thlaspion rotundifolii, groups 5 and 2), whereas windy (Elynion) and dry (Seslerion) calcareous grasslands colonized the highest elevation of the pass (group 1). The highest plant diversity was found in Les Martinets because this site presents the highest geomorphological diversity and all types of ESPs. The vegetation plots there belonged to all five groups.

\section{Ground Surface Temperatures}

The temperature distribution within two years of GST monitoring (01.10.2016-30.09.2018) is presented in Supplementary material Figure S3. During the study period, the snow arrived late in the 2016-2017 winter season and the snow cover thickness remained below average. Then, early snow melt coupled with warm air temperatures during early summer led to high ground surface temperatures during the snow free period (Meteoswiss, 2018). Instead, winter 2017-2018 had thicker and longer snow cover and mild air temperatures, which maintained GSTs around $0^{\circ} \mathrm{C}$ in most of the site. Air temperatures of the 2018 summer in Switzerland were among the highest ever recorded, overstepping the 19812010 mean (Meteoswiss, 2019). Consequently, the ground in the study area warmed more than the year before. Therefore, high variability was observed: the minimum winter temperatures were $-13.1{ }^{\circ} \mathrm{C}$ on 2017 (Col des Perris Blancs, plot $\mathrm{n}^{\circ} 44$ on 24 January) and $-8.9^{\circ} \mathrm{C}$ on 2018 (Col des Perris Blancs, plot $\mathrm{n}^{\circ} 44$ on 2 March) and maximum summer temperatures were $21.9^{\circ} \mathrm{C}$ on 2017 (Les Outans, plot $n^{\circ} 52$ on 24 June) and $23.3^{\circ} \mathrm{C}$ on 2018 (Les Martinets, plot $\mathrm{n}^{\circ} 1$ on 1 July).

The vegetation plots corresponding to groups 1 and 2 (see Table V) had the highest MGST (3.6 and $3.1^{\circ} \mathrm{C}$, respectively) and Tmax (4.9 and $4.5^{\circ} \mathrm{C}$, respectively) and the longest GSL (109 and 105 days, respectively). The plots of groups 3 and 4 had the lowest MGST $\left(2.5^{\circ} \mathrm{C}\right)$ and $\operatorname{Tmax}\left(3.6^{\circ} \mathrm{C}\right)$ but the group 3 had also the lowest FDD index (47 degree days), whereas the plots in group 4 had the lowest GDD (922 degree days) and GSL (80 days). The plots in group 5 had the lowest Tmin ($0.2^{\circ} \mathrm{C}$ ) and the highest FDD index (233 degree days), even if MGST and Tmax were in average.

Table V. Environmental characteristics of the five vegetation groups. Mean values and standard deviations are reported. Species richness: number of species per plot. Evenness: biodiversity index measuring the dominance of one species above the others in the same plot. Elevation: [meters]. Aspect: North $(-1)$ South $(+1)$ gradient. Slope: [degrees]. MGST: Mean Ground Surface Temperature $\left[{ }^{\circ} \mathrm{C}\right]$. Tmax: mean maximum temperature $\left[{ }^{\circ} \mathrm{C}\right]$. Tmin: mean minimum temperature $\left[{ }^{\circ} \mathrm{C}\right]$. FDD: Freezing Degree Day [degree day]. GDD: Growing Degree Day [degree day]. GSL: Growing Season Length [day]

\begin{tabular}{|c|c|c|c|c|c|c|}
\hline Groups & Number of plots & Species richness & Evenness & Elevation & Aspect & Slope \\
\hline 1 & 19 & $17 \pm 4$ & $0.25 \pm 0.08$ & $2281 \pm 185$ & $-0.33 \pm 0.69$ & $20 \pm 9$ \\
\hline 2 & 14 & $11 \pm 5$ & $0.50 \pm 0.20$ & $2269 \pm 158$ & $-0.52 \pm 0.56$ & $21 \pm 6$ \\
\hline 3 & 16 & $13 \pm 4$ & $0.35 \pm 0.11$ & $2315 \pm 48$ & $-0.39 \pm 0.71$ & $24 \pm 11$ \\
\hline 4 & 9 & $8 \pm 3$ & $0.61 \pm 0.19$ & $2355 \pm 94$ & $-0.24 \pm 0.79$ & $21 \pm 12$ \\
\hline 5 & 13 & $9 \pm 3$ & $0.40 \pm 0.10$ & $2353 \pm 194$ & $-0.54 \pm 0.41$ & $24 \pm 8$ \\
\hline Groups & MGST & Tmax & Tmin & FDD & GDD & GSL \\
\hline 1 & $3.6 \pm 0.5$ & $4.9 \pm 0.6$ & $1.1 \pm 0.5$ & $85 \pm 88$ & $1429 \pm 144$ & $109 \pm 9$ \\
\hline 2 & $3.1 \pm 0.7$ & $4.5 \pm 1.0$ & $0.8 \pm 0.7$ & $82 \pm 153$ & $1151 \pm 305$ & $105 \pm 48$ \\
\hline 3 & $2.5 \pm 0.6$ & $3.6 \pm 1.1$ & $0.7 \pm 0.3$ & $47 \pm 61$ & $965 \pm 255$ & $84 \pm 14$ \\
\hline 4 & $2.5 \pm 0.5$ & $3.6 \pm 0.8$ & $0.6 \pm 0.5$ & $87 \pm 94$ & $922 \pm 182$ & $80 \pm 14$ \\
\hline 5 & $2.6 \pm 0.8$ & $4.1 \pm 0.9$ & $-0.2 \pm 1.6$ & $233 \pm 239$ & $1176 \pm 217$ & $100 \pm 14$ \\
\hline
\end{tabular}


The basal-ripening date (RD) was not present for all data loggers due to a lack of ground freezing in some cases. As a result, it was calculated for only 40 plots in 2017 and for 9 in 2018. The earliest date when the ground temperature reached $0^{\circ} \mathrm{C}$ was 1 February 2017 (plot $n^{\circ}$ 53), whereas the latest date was 31 May 2017 (plot $n^{\circ}$ 30). In 2018, the RDs were between April and May. The melt-out date was detected for all data loggers. The snowmelt started earlier in 2017 than in 2018. In 2017, the snow disappeared first at the plot $n^{\circ} 44$ on 22 May and lastly at the plot $n^{\circ} 11$ on 21 July. In 2018, it disappeared first at the plot $n^{\circ} 18$ on 30 June and lastly at the plot $n^{\circ} 27$ on $2 \mathrm{Au}-$ gust. Examples of two typical curves of temperature evolution are reported in Supplementary material Figure S4.

The FDD index points out the coldest areas: these were located on the debris-covered glacier in Les Outans (plots $n^{\circ} 47$ and 52), at the Col des Perris Blancs, especially on the protalus rampart (plots $\mathrm{n}^{\circ} 43,44,62,63$ ), and in the upper part of the Martinets rock glacier and in the lateral morainic deposit (plots $n^{\circ} 19,20$ and 30 - Figure 2). On the same locations, daily temperatures below $-2^{\circ} \mathrm{C}$ were recorded on late winter, before the RD. During 2016-2017 winter, temperatures below $-3^{\circ} \mathrm{C}$ were recorded at the plots $n^{\circ} 19,43,44,47,62,63,64$ and 69; during 2017-2018 winter, at the plots $n^{\circ} 43,44$ and 62 . These data indicate a possible presence of permafrost.

\section{Vegetation-environment relationships}

The NMDS offers a graphical visualization of the vegetation plots distributed according to plant composition. Their disposition reflects the previous clustering in five groups, although the elements in group 2 are scattered. The ordination stress was 0.22 (Figure 3). Among the environmental factors added with the envfit function to test for the correlation with plant communities, morphodynamics was the most explicative variable with the highest value of linear fit $\left(R^{2}=57 \%\right)$, followed by GDD $\left(R^{2}=50 \%\right)$, MGST and $\operatorname{Tmax}\left(R^{2}=32 \%\right)$, rill erosion and FDD $\left(R^{2}=23 \%\right)$, GSL $\left(R^{2}=20 \%\right)$, Tmin $\left(R^{2}=19 \%\right)$ and solifluction $\left(R^{2}=17 \%\right)$, all with $p$-value $<0.001$ (linear
Table VI. Correlations between NMDS axes and explained variables. NMDS1 and NMDS2 are the axis scores about the 2D ordination space. $\mathrm{R}^{2}=$ linear fit of correlation. Signif.: indicate the $p$-value. ${ }^{* *} \leq$ $0.001 ; * * \leq 0.01 ; * \leq 0.05 ; . \leq 0.1 ; \mathrm{ns}=$ not significant. GSL $=$ Growing Season Length; GDD = Growing Degree Day; FDD = Freezing Degree Day; TVDI = Temperature Vegetation Dryness Index; MGST = Mean Ground Surface Temperature; Tmax and Tmin = maximum and minimum temperature

\begin{tabular}{lllcl}
\hline & NMDS1 & NMDS2 & $\mathbf{R}^{\mathbf{2}}$ & Signif. \\
\hline Morphodynamics & 0.83 & 0.56 & 0.57 & $* * *$ \\
GDD & -0.73 & 0.68 & 0.50 & $* * *$ \\
MGST & -0.89 & 0.46 & 0.32 & $* * *$ \\
Tmax & -0.59 & 0.81 & 0.32 & $* * *$ \\
Rill_erosion & 0.35 & 0.94 & 0.23 & $* * *$ \\
FDD & -0.17 & -0.99 & 0.23 & $* * *$ \\
GSL & -0.88 & 0.48 & 0.20 & $* * *$ \\
Tmin & -0.50 & -0.87 & 0.19 & $* * *$ \\
Solifluction & 0.31 & 0.95 & 0.17 & $* * *$ \\
Frost_weathering & 0.28 & 0.96 & 0.12 & $*$ \\
TVDI & -0.94 & 0.34 & 0.10 & $*$ \\
Nivation & 0.09 & -1.00 & 0.10 & $*$ \\
Slope & 0.48 & 0.88 & 0.09 & $*$ \\
Elevation & 0.55 & -0.84 & 0.04 & $\mathrm{~ns}$ \\
Aspect & -0.33 & -0.94 & 0.04 & $\mathrm{~ns}$ \\
\hline
\end{tabular}

correlation). Frost weathering, TVDI and nivation influenced less the vegetation composition $\left(R^{2} \leq 12 \%\right.$; $p$-value $\left.<0.05\right)$ and slope had the lowest influence $\left(R^{2}=9 \% ; p\right.$-value $\left.<0.1\right)$. Elevation and aspect were not significantly correlated. More details are reported in Table VI. The linear and smoothed surface fits indicate clear gradients in surface activity corresponding to community structure (Figure 4).

Based on the results of the Spearman correlation, MGST, Tmin and Tmax were all correlated and GDD was correlated with MGST, Tmax and GSL (values > 10.7l; see Supplementary material Figure S5). Then, to calculate the GLMs and GAMs, only GDD plus the other variables were added.

The significant baseline variables used to model species cover with the GLM were FDD, GDD and elevation, whereas

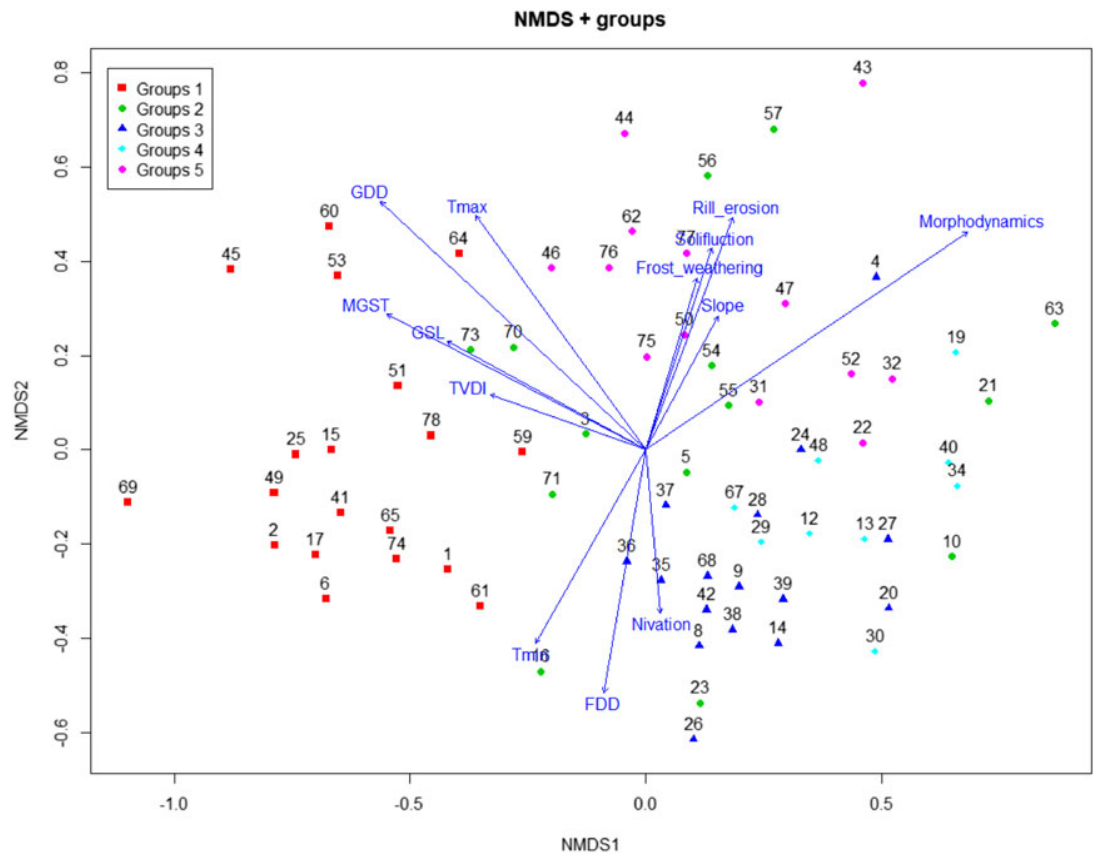

Figure 3. NMDS biplot of the vegetation plots, based on the Bray-Curtis dissimilarity matrix, with fitted vectors of all environmental factors. The plot data are regrouped in 5 groups. Ordination stress = 0.22. GSL = Growing Season Length; GDD = Growing Degree Day; FDD = Freezing Degree Day; MGST = Mean Annual Ground Surface Temperature; TVDI = Temperature Vegetation Dryness Index. [Colour figure can be viewed at wileyonlinelibrary.com] 

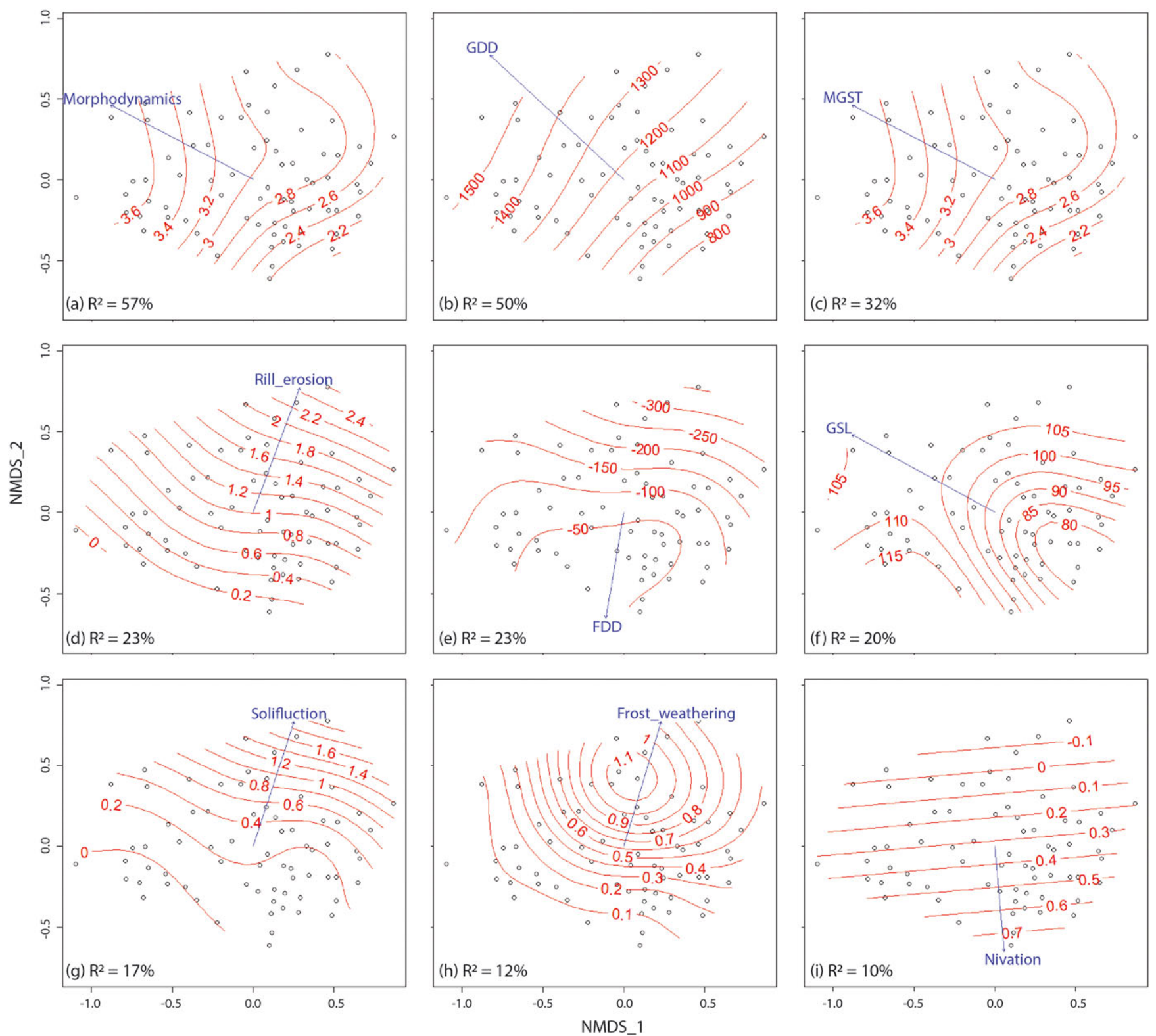

Figure 4. Relationship between the plant community (black points; ordination conducted using NMDS) and the environmental variables that are the most significant. The blue vectors indicate the direction of maximum linear correlation (ordination score reported in percentage). The red smoothed surface fits represent the change of the variable between the plots. The $p$-value of vectors is $<0.001$ for (a)-(g) and $<0.05$ for (h)-(i). GSL $=$ Growing Season Length; GDD = Growing Degree Day; FDD = Freezing Degree Day; TVDI = Temperature Vegetation Dryness Index. [Colour figure can be viewed at wileyonlinelibrary.com]

GDD and elevation were used with the GAM because their inclusion in the models was significant $(p$-value $<0.1)$. To model species richness, the baseline variables of the GLM and GAM were FDD, GDD and slope ( $p$-value < 0.05).

The best GLM prediction of species cover was achieved using quadratic terms and family argument "quasipoisson". The explained deviance was $45.7 \%$ for the baseline model and $71.9 \%$ for the advanced model. In the other case, it was lower (41$45.7 \%$ and $64.1-67.1 \%$ ). The details of all trials with quadratic terms and the family argument "quasibinomial" are presented in Supplementary material Figure S6. The predictions of species cover and species richness were significantly improved by the addition of the morphodynamics variable ( $p$-value $<0.001)$. For species cover, the explained deviance improved from $43.3 \%$ to $70.8 \%$ using the GAM. For species richness, the explained deviance in the GLM changed from $31.2 \%$ to $52.6 \%$, and in the GAM from $32.7 \%$ to $55.4 \%$. According to the GLM results, species richness increased as GDD $(p$-value $<0.05)$ increased and decreased as morphodynamics ( $p$-value $<$ $0.001)$, FDD ( $p$ value $<0.05)$ and slope increased ( $p$ value $<$ $0.1)$. As long as the models are linear, no figures are shown. From the GAM results, the species cover increased as GDD ( $p$-value $<$ 0.001 ) and elevation (but $p$-value not significant) increased (Figure $5 \mathrm{a}$ and b), whereas it decreased significantly ( $p$-value < 0.001 ) with an increase in morphodynamics (Figure 5c). Species richness increased as GDD increased ( $p$-value not significant Figure $5 \mathrm{~d}$ ) and decreased as FDD ( $p$-value $<0.01$ ), slope (not significant) and morphodynamics ( $p$-value $<0.001$ ) increased (Figure $5 \mathrm{e}$ and $\mathrm{f}$ ).

\section{Discussion}

In the present study, we investigated the influence of environmental variables, especially geomorphic processes, on the composition of plant communities in the Western Swiss Alps. 
a)

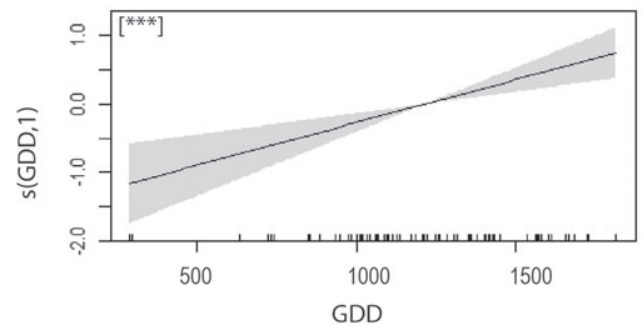

c)

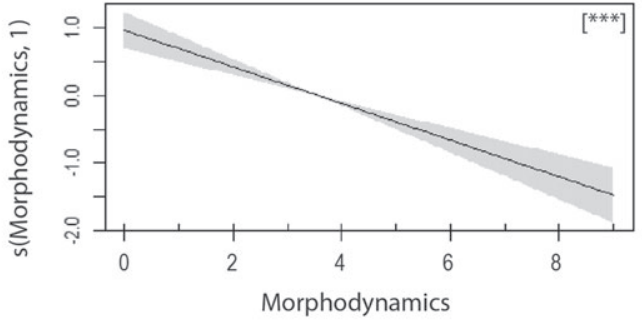

d)

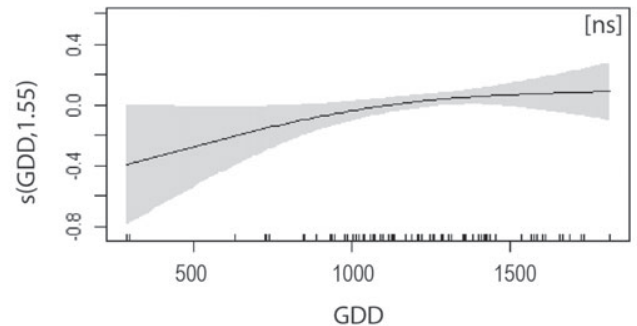

f)

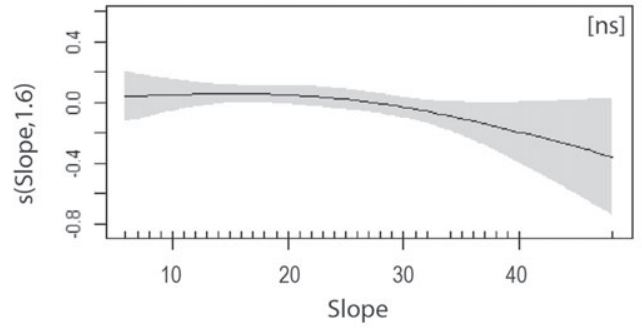

b)

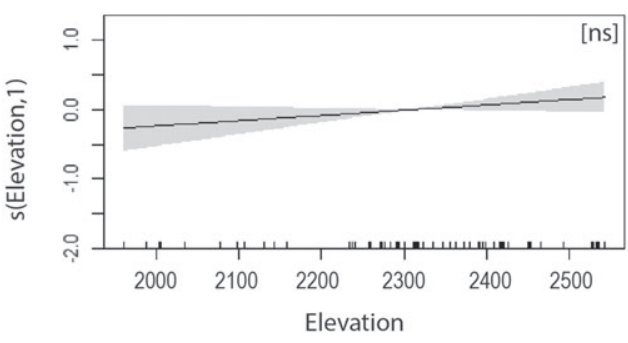

e)

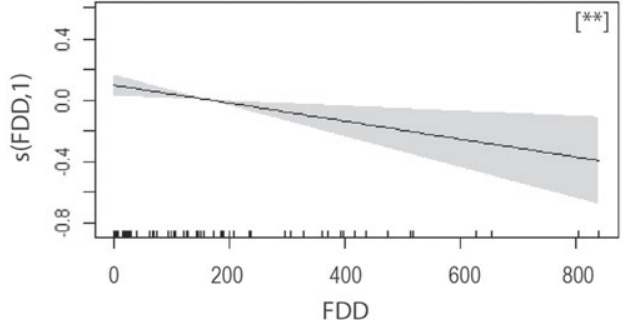

g)

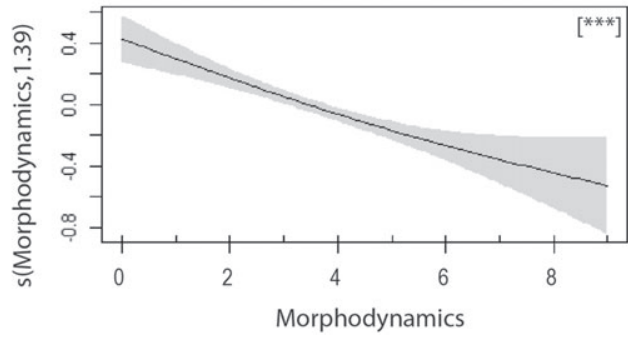

Figure 5. Species cover (a-c) and species richness ( $d-f)$ models conducted using GAMs. (a-b) and (d-f) represent the baseline explanatory variables, (c) and (g) the environmental variables added to improve models. The $\mathrm{x}$-axis represents the environmental variables and the $y$-axis the smoothed factor of the variable with estimated degrees of freedom. Shaded area represents the confidence interval. GDD = Growing Degree Day. FDD $=$ Freezing Degree Day. Symbols between [] indicate statistical significance. $\left.{ }^{* * *}\right]=$ p-value $\left.<0.001 ;{ }^{*}\right]=p$-value $<0.05 ;[]=$.$p -values <0.1 ;[$ ss $]=$ not significant.

The innovative aspect of this research is that we have worked on sites characterized by a high degree of heterogeneity regarding ages, landforms and plant communities, using a large dataset including vegetation and temperature. Indeed, to enhance plant species distribution model, not only improving the resolution of topographic data is important but also conducting thorough field measurements (Pradervand et al., 2014), as in our case. We expected microtopography, microclimate, soil moisture, snow cover and ESPs to be the most important environmental factors for plant communities. However, the initial expectations were only partly confirmed. Our results highlighted that landform morphodynamics (which acts on microtopography), growing degree days and mean ground surface temperature were the most explicative environmental variables for community composition and species richness. Indeed, different geomorphological characteristics support different plant communities, depending on age, soil development, frequency of disturbances and landforms dynamics, confirming previous studies (e.g., Gentili et al., 2013; le Roux and Luoto, 2014). However, the ESPs and the temperature vegetation dryness index (TVDI) exhibited low statistical significance in our analysis, even if the TVDI is likely directly correlated to vegetation properties because it includes the NDVI.
Considerable heterogeneity not affected by spatial autocorrelation was observed among the plant communities in all three focus sites. Indeed, due to the heterogeneity of landforms, characterized by different ages and stability, we found a high diversity of plant communities from pioneer, typical of young moraine deposits, to stable communities, typical of alpine grasslands. As expected, species cover and species richness were positively correlated with each other and negatively correlated with evenness (Stirling and Wilsey, 2001). Furthermore, their values were lower in the plots characterized by ESPs. The composition of the different plant communities is constrained by the respective adaptations of the species to environmental conditions. In Les Outans, superficial processes (rill erosion, debris flow, rock falls) affecting wet calcareous screes and subsidence due to ice melt on the debris-covered glacier resulted in the survival of only pioneer species. Indeed, the superficial processes maintain pioneer vegetation groups (Moreau et al., 2008). In the Col des Perris Blancs, pioneer species were present on poorly developed soils and solifluction areas. In contrast, windy and dry alpine grasslands were identified in areas not modified by the LIA glacier, which were characterized by well-developed organic soil. Les Martinets site showed the highest plant community diversity. Indeed, the complex history 
of this catchment (Perret and Martin, 2015) results in the establishment of a large variety of successional stages, from pioneer species in the recently deglaciated areas (observed in the plots belonging to Thlaspion rotundifolii and Drabion hoppeanae) to late successional grasslands in the stable surfaces of the Holocene period (Elynion, Seslerion, Caricion ferrugineae and Caricion curvulae).

Monitoring of ground surface temperatures was helpful in documenting the microclimatology of the study area and evaluating the possible presence of permafrost. During the monitoring period (October 2016 - September 2018), the thin snowpack at the beginning of winter 2016/2017 induced a low insulation and, consequently, a strong overcooling of the winter GST, which was the lowest recorded in the Swiss Alps over the last ten years (PERMOS, 2019). In contrast, winter $2017 / 2018$ was characterized by a thicker and longer snow cover that, together with warmer air temperatures, maintained GST higher than in 2017. The FDD analysis and the negative daily temperatures highlighted where the coolest sites were located in the study areas. According to the BTS method (Haeberli, 1973; Hoelzle et al., 1993; Ikeda and Matsuoka, 2002; Ishikawa, 2003), permafrost is present around the Col des Perris Blancs area and in the upper part of the rock glacier in Les Martinets above 2400 ma.s.l. because winter temperatures below thick snow were lower than $-2^{\circ} \mathrm{C}$ (and locally $-3^{\circ} \mathrm{C}$ ). This was also confirmed by an electrical resistivity tomography profile (Giaccone et al., 2016). Negative BTS were also reported for Les Outans debris-covered glacier, due to the presence of glacier ice close to the surface. The warmer temperatures measured on the lower part of the Martinets rock glacier does not exclude permafrost conditions. They can indeed be explained by a thick active layer that prevents the detection of cold ground conditions by the BTS method. Eventually, the outlining of these cold sectors fit well with the Alpine Permafrost Index Map (Boeckli et al., 2012) and with previous geomorphological analyses (Lambiel et al., 2009; Perret and Martin, 2015). However, temperature was less correlated to the NMDS axes than GDD and, due to the high correlation between these variables ( 0.8 with Tmin and MGST), only GDD was finally used in vegetation models.

While the rock glacier in Les Martinets suggests the presence of permafrost in the upper part, landform dynamics and related topography were more important to explain the distribution of vegetation types (e.g., Gobbi et al., 2014; Colombo et al., 2016). Besides, the active layer thickness prevents any influence of permafrost on plant life (van Tatenhove and Dikau, 1990; Körner, 2003). In Les Martinets, the lower part of the rock glacier had vegetation patches of late-successional stages (grassland), whereas the upper part was colonized exclusively by pioneer species. In most cases, grass species were found in Salix retusa and $S$. serpillifolia mats. This was because dwarf Salix species, due to their creeping growth and abundant root development, promote debris stabilization, the accumulation of fine sediments, biomass and humus thus facilitating the colonization of other species (Reisigl and Keller, 1987). These elements, together with morphological indices, suggest that the lower part of the rock glacier is older than the upper part. Furthermore, no evident signs of movements were visible in the frontal part of the lower lobe, in contrast to the upper part where the front is less stable. Thus, the vegetation allows us to discern between active and inactive rock glaciers, as also shown by Cannone and Gerdol (2003) and Burga et al. (2004).

Microtopography controls soil moisture patterns and nutrient availability (Kemppinen et al., 2018), playing a major role in the development of vegetation types and plant community succession (Stewart et al., 2014; Riihimäki et al., 2017), and generates habitats with heterogeneous snow distribution (Hülber et al., 2010; Aalto et al., 2018), which also influences plant communities. For example, places where the snow disappears later in summer, as in the Col des Perris Blancs and Les Martinets sites, were mainly colonized by snowbed species (e.g. Arabis caerulea, Salix herbacea). Based on correlations between vegetation plots and environmental variables, the growing degree days and the growing season length appeared to be between the most explicative variables, confirming how snow persistence influences vegetation communities (Braun, 1913; Niittynen and Luoto, 2018).

NMDS analysis was decisive in identifying the influence of environmental parameters on alpine plant communities, even if the ordination stress was high (Clarke, 1993), which could cause misinterpretation. Nevertheless, a relatively low number of dimensions was needed to obtain the best fit (Hair et al., 2014). Including the landform morphodynamics variable in the NMDS was crucial to explaining plant communities, as this variable exhibited the highest value of linear fit $\left(R^{2}=57 \%\right)$. Furthermore, it significantly improved the species cover and species richness predictions with both the GLMs and GAMs. It was, indeed, the only significant variable $(p$-value $<0.001)$ among those added to the baseline GLM and GAM that augmented the explained deviance in both models. We demonstrated that higher landform morphodynamics cause a decrease in species cover and species richness. Examples are the plots $n^{\circ} 11,12,43$ and 44 , the first two of which were located at the front of the higher lobe of the rock glacier in Les Martinets, and the latter two were located in the protalus rampart in the Col des Perris Blancs. These plots are characterized by a maximum morphodynamics index and low level of species cover (0-10\%) and species richness (max 8 species).

However, contrary to our initial expectations, solifluction, rill erosion and nivation were not significant in the species cover and species richness models, although ESPs were shown to be influential on plant communities in previous studies (Malanson et al., 2012; le Roux et al., 2013). The reason for this difference may result from an insufficient sample size to fit the GLMs and GAMs, as evidences of ESPs were only found in a limited number of plots. The plots most affected by rill erosion, solifluction and frost weathering are included in groups 2 and 5 . In these groups, the species belong to Petasidion paradoxi, Thlaspion rotundifolii and Drabion hoppeanae, all being markers of calcareous screes (Delarze et al., 2015), with high rates of geomorphic processes. The plots characterized by nivation were found in groups 2 and 3 (composed of species belonging to Arabidion caeruleae, Salicion herbaceae, Thlaspion rotundifolii and Drabion hoppeanae) and were located in small areas, where the local topography supports longer snow persistence and, consequently, the growth of snowbed species (Björk \& Molau, 2007). The plots not affected by ESPs were composed of late successional species and pioneer species.

The choice to include the morphodynamics index in our analysis was fundamental even if it has some limitations. Indeed, the relationships between species composition and landform morphodynamics derive from the effect of landform changes (e.g. Cannone \& Gerdol, 2003; Gentili et al., 2013; le Roux and Luoto, 2014) and direct disturbance impact on species, but also from other factors which were not integrated in our index. Within the morphodynamics index, we took into consideration the soil texture and development (fine material or rock texture) but not $\mathrm{pH}$, nutrients, quantitative soil organic matter and other soil properties, which are also known to be essential for plant species development, for example ions concentration, water content and soil respiration (Buri et al., 2017; Cianfrani et al., 2018; Gobat et al., 2010; Grand et al., 2016; Matteodo et al., 2018). Furthermore, soil properties are particularly difficult to include in the models due to their high 
spatial variability, which depends on bedrock, climate and topographical factors, but also on the activity of microorganisms (e.g. Yashiro et al., 2018). A further complication is that they are tightly associated to vegetation, and vice versa (Lavelle et al., 1995; Guisan et al., 1998).

Our results confirmed also the importance of the thermal indices for plant species. Climatic factors are in fact between the most important factors shaping plant distributions and especially the temperature is a key parameter influencing plant life cycles. Under ongoing climate warming, several studies have pointed out that phenology is accelerated and growth enhanced (Hollister et al., 2005; Chen et al., 2015) but freezing and heat stress still played decisive roles for alpine plants life (Körner, 2003).

\section{Conclusion}

In this study, we investigated three alpine sites in the Western Swiss Alps (1950-2550 m a.s.l.) that exhibited high geomorphological variability and habitat diversity. We demonstrated that landform morphodynamics, growing degree days and mean ground surface temperature are the most explicative environmental variables of plant communities in such heterogeneous environments. Specifically, the morphodynamics index proved fundamental as it provided important information concerning landform stability, frequency of disturbances, age of deposits and soil development. Moreover, vegetation shows to be critically relevant to identify the different degrees of activity in the rock glacier.

The morphodynamics index significantly improved the models of species cover and species richness. The earth surface processes (rill erosion, solifluction, frost weathering and nivation) are also known to influence vegetation types (Virtanen et al., 2010; le Roux and Luoto, 2014) but were less significant in our study. However, in the plots characterized by earth surface processes (ESPs), vascular plant cover and species richness had lower values compared to the "No ESP" category, indicating that an increase in geomorphological disturbance causes a reduction in the number of species and their cover percentage. Furthermore, high species richness values were generally associated with low morphodynamics index. Therefore, our results do not support the intermediate disturbance hypothesis (Connell, 1978), which asserts that maximum species richness should be reached at intermediate intensities of disturbance. Nevertheless, in alpine environments, this hypothesis should not be evaluated as the only explanation because other important abiotic factors, such as temperature, length of growing season and soil pH, are more actively involved (Vonlanthen et al., 2006b). Part of these factors induce probably too stressful conditions to allow competitive species to dominate the communities and to exclude stress tolerant species, as observed in lowlands with forests.

The results of this study contribute to a better understanding of the environmental factors influencing the type and distribution of alpine plant communities. Subjected to persistent atmospheric warming, changes in ground surface temperatures, snow cover and correlated earth surface processes may directly modify plant communities and soil properties. Future research should investigate the effects of soil texture, nutrient and $\mathrm{pH}$, as done by Dubuis et al. (2013), and couple these results with geomorphological assessment in high alpine sites, as those presented here. Additionally, it would be important to work with longer ground surface temperature series, to obtain a more complete overview of the factors affecting vegetation in alpine ecosystems, and to take in consideration a biogeomorphic approach, because plant communities and geomorphic disturbance regime could be co-dependent as demonstrated by some authors (e.g., Corenblit and Steiger, 2009; Eichel et al., 2016 and 2017; Lane et al., 2016).

Acknowledgements - This research is part of the project "Integrating spatial predictions of vegetation, soils, geomorphology and hydrology for improved assessment of ecosystem services under climate change", supported by the Swiss National Science Foundation (project $\mathrm{N}^{\circ}$ CR23I2_162754). The Vaud Alps, where this research is carried out, are a priority research area for the University of Lausanne (http:// rechalp.unil.ch).

\section{Bibliography}

Aalto J, Scherrer D, Lenoir J, Guisan A, Luoto M. 2018. Biogeophysical controls on soil-atmosphere thermal differences: implications on warming Arctic ecosystems. Environmental Research Letters 13(7): 74003.

Acquaotta F, Fratianni S, Garzena D. 2015. Temperature changes in the North-Western Italian Alps from 1961 to 2010. Theoretical and Applied Climatology 122(3): 619-634.

Alatalo J, Jägerbrand A, Molau U. 2016. Impacts of different climate change regimes and extreme climatic events on an alpine meadow community. Scientific Reports 6: 21720.

Anderson S, Drever J, Frost C, Holden P. 2000. Chemical weathering in the foreland of a retreating glacier. Geochimica et Cosmochimica Acta 64(7): 1173-1189.

Auer I, Böhm R, Jurkovic A, Lipa W, Orlik A, Potzmann R et al. 2007. HISTALP_historical instrumental climatological surface time series of the Greater Alpine Region. International Journal of Climatology 27(1): 17-46

Badoux H. 1991. Aperçu géologique du Vallon de Nant. In La Thomasia. Jardin alpin de Pont de Nant 1891-1991. Musées et jardins botaniques cantonaux: Lausanne; 37-43.

Ballantyne C. 2002. Paraglacial geomorphology. Quaternary Science Reviews 21(18-19): 1935-2017.

Baroni C, Armiraglio S, Gentili R, Carton A. 2007. Landform-vegetation units for investigating the dynamics and geomorphologic evolution of alpine composite debris cones (Valle dell'Avio, Adamello Group, Italy). Geomorphology 84(1-2): 59-79.

Baroni C, Gentili R, Armiraglio S. 2013. Vegetation analysis on composite debris cones. In Dating Torrential Processes on Fans and Cones: Methods and Their Application for Hazard and Risk Assessment, Schneuwly-Bollschweiler M, Stoffel M, Rudolf-Miklau F (eds). Springer: Netherlands Dordrecht; 187-201.

Béguin C, Progin Sonney M, Vonlanthen M. 2009. Le cortège floristique des sols polygonaux dans les Alpes valaisannes. Bulletin de la Murithienne 126: 47-51.

Beniston M. 2005. Mountain climates and climatic change: an overview of processes focusing on the European Alps. Pure and Applied Geophysics 162(8-9): 1587-1606.

Beniston M, Farinotti D, Stoffel M, Andreassen L, Coppola E, Eckert N et al. 2018. The European mountain cryosphere: a review of its current state, trends, and future challenges. The Cryosphere 12(2): 759-794.

Boeckli L, Brenning A, Gruber S, Noetzli J. 2012. Permafrost distribution in the European Alps: calculation and evaluation of an index map and summary statistics. The Cryosphere 6(4): 807-820.

Björk RG, Molau U. 2007. Ecology of alpine snowbeds and the impact of global change. Arctic, Antarctic, and Alpine Research 39: 34-43.

Braun J. 1913. Die Vegetationsverhältnisse der Schneestufe in den Rätisch-Lepontischen Alpen. Ein Bild des Pflanzenlebens an seinen äussersten Grenzen. Neue Denkschriften der Schweizerischen Naturforschenden Gesellschaft 48 : 1-347.

Braun-Blanquet J. 1932. Plant sociology; the study of plant communities. McGraw-Hill: New York and London.

Bray RJ, Curtis JT. 1957. An ordination of the upland forest communities of southern Wisconsin. Ecological Monographs 27: 325-349.

Burga C, Frauenfelder R, Ruffet J, Hoelzle M, Kääb A. 2004. Vegetation on Alpine rock glacier surfaces: a contribution to abundance and 
dynamics on extreme plant habitats. Flora - Morphology, Distribution, Functional Ecology of Plants 199(6): 505-515.

Burga C, Krüsi B, Egli M, Wernli M, Elsener S, Ziefle M et al. 2010. Plant succession and soil development on the foreland of the Morteratsch glacier (Pontresina, Switzerland): Straight forward or chaotic? Flora Morphology, Distribution. Functional Ecology of Plants 205(9): 561-576.

Buri A, Cianfrani C, Pinto-Figueroa E, Yashiro E, Spangenberg J, Adatte T et al. 2017. Soil factors improve predictions of plant species distribution in a mountain environment. Progress in Physical Geography: Earth and Environment 41(6): 703-722.

Cannone N, Gerdol R. 2003. Vegetation as an ecological indicator of surface instability in rock glaciers. Arctic, Antarctic, and Alpine Research, 35(3): 384-390.

Chen X, An S, Inouye D, Schwartz M. 2015. Temperature and snowfall trigger alpine vegetation green-up on the world's roof. Global Change Biology 21(10): 3635-3646.

Cianfrani C, Buri A, Verrecchia E, Guisan A. 2018. Generalizing soil properties in geographic space: Approaches used and ways forward. (B. Minasny, Éd.). PLoS ONE 13(12): e0208823.

Clarke KR. 1993. Non-parametric multivariate analyses of changes in community structure. Australian Journal of Ecology 18(1): 117-143.

Colombo N, Giaccone E, Paro L, Buffa G, Fratianni S. 2016. The recent transition from glacial to periglacial environment in a high altitude alpine basin (Sabbione basin, north-western Italian Alps). Preliminary outcomes from a multidisciplinary approach. Geografia Fisica e Dinamica Quaternaria 39(1).

Connell JH. 1978. Diversity in tropical rain forests and coral reefs. Science 199(4335): 1302-1310.

Corenblit D, Baas A, Bornette G, Darrozes J, Delmotte S, Francis R et al. 2011. Feedbacks between geomorphology and biota controlling Earth surface processes and landforms: A review of foundation concepts and current understandings. Earth-Science Reviews 106(3): 307-331.

Corenblit D, Steiger J. 2009. Vegetation as a major conductor of geomorphic changes on the Earth surface: toward evolutionary geomorphology. Earth Surface Processes and Landforms 34(6): 891-896.

Crawley MJ. 2007. Generalized linear models. The R book. John Wiley \& Sons: Chichester, 511-526.

Delarze R, Gonseth Y, Eggenberg S, Vust M. 2015. Guide des milieux naturels de Suisse. Ecologie, menaces, espèces caractéristiques. 3rd ed. Rossolis: Bussigny.

Dormann C, Elith J, Bacher S, Buchmann C, Carl G, Carré G et al. 2013. Collinearity: a review of methods to deal with it and a simulation study evaluating their performance. Ecography 36(1): 27-46.

Dubuis A, Giovanettina S, Pellissier L, Pottier J, Vittoz P, Guisan A. 2013. Improving the prediction of plant species distribution and community composition by adding edaphic to topo-climatic variables. Journal of Vegetation Science 24(4): 593-606.

Dullinger S, Gattringer A, Thuiller W, Moser D, Zimmermann N, Guisan A et al. 2012. Extinction debt of high-mountain plants under twenty-first-century climate change. Nature. Climate Change 2: 619 .

Dutoit A. 1983. La végétation de l'étage subalpin du vallon de Nant. Section protection de la nature et des sites et conservation de la faune du Canton de Vaud: Lausanne.

Eichel J, Corenblit D, Dikau R. 2016. Conditions for feedbacks between geomorphic and vegetation dynamics on lateral moraine slopes: a biogeomorphic feedback window. Earth Surface Processes and Landforms 41(3): 406-419.

Eichel J, Draebing D, Klingbeil L, Wieland M, Eling C, Schmidtlein S et al. 2017. Solifluction meets vegetation: the role of biogeomorphic feedbacks for turf-banked solifluction lobe development. Earth Surface Processes and Landforms 42(11): 1623-1635.

Franklin J. 2010. Mapping species distributions: spatial inference and prediction. Cambridge University Press.

Füssel H-M, Jol A, Marx A, Hildén M, Aparicio A, Bastrup-Birk A et al. 2017. Climate change, impacts and vulnerability in Europe 2016-An indicator-based report. European Environment Agency (EEA) Report No 1 .
Gentili R, Armiraglio S, Rossi G, Sgorbati S, Baroni C. 2010. Floristic patterns, ecological gradients and biodiversity in the composite channels (Central Alps, Italy). Flora - Morphology, Distribution, Functional Ecology of Plants 205(6): 388-398.

Gentili R, Armiraglio S, Sgorbati S, Baroni C. 2013. Geomorphological disturbance affects ecological driving forces and plant turnover along an altitudinal stress gradient on alpine slopes. Plant Ecology 214(4): 571-586.

Giaccone E, Mariéthoz G, Lambiel C. 2016. Interactions between geomorphology and vegetation in the Vaud Alps: first investigations. Abstract Volume 14th Swiss Geoscience Meeting Geneva 10: 369-370.

Gobat J-M, Aragno M, Matthey W. 2010. Le sol vivant. Bases de pédologie-Biologie des sols. 3rd ed. Presses polytechniques et universitaires romandes: Lausanne, $848 \mathrm{pp}$.

Gobbi M, Ballarin F, Compostella C, Lencioni V, Seppi R, Tampucci D, Caccianiga M. 2014. Physical and biological features of an active rock glacier in the Italian Alps. The Holocene 24(11): 1624-1631.

Gobiet A, Kotlarski S, Beniston M, Heinrich G, Rajczak J, Stoffel M. 2014. 21 st century climate change in the European Alps-A review. Science of the Total Environment 493: 1138-1151.

Gottfried M, Pauli H, Futschik A, Akhalkatsi M, Barančok P, Alonso J et al. 2012. Continent-wide response of mountain vegetation to climate change. Nature Climate Change 2(2): 111.

Grand S, Rubin A, Verrecchia E, Vittoz P. 2016. Variation in Soil Respiration across Soil and Vegetation Types in an Alpine Valley. (W. Araujo, Éd.). PLoS ONE 11(9): e0163968.

Gubler S, Fiddes J, Keller M, Gruber S. 2011. Scale-dependent measurement and analysis of ground surface temperature variability in alpine terrain. The Cryosphere 5(2): 431-443.

Guisan A, Edwards T, Hastie T. 2002. Generalized linear and generalized additive models in studies of species distributions: setting the scene. Ecological Modelling 157(2): 89-100.

Guisan A, Theurillat J-P, Kienast F. 1998. Predicting the Potential Distribution of Plant Species in an Alpine Environment. Journal of Vegetation Science 9(1): 65-74.

Haeberli W. 1973. Die Basis-Temperatur der winterlichen Schneedecke als möglicher Indikator für die Verbreitung von Permafrost in den Alpen. Zeitschrift für Gletscherkunde und Glazialgeologie 9: 221-227.

Haeberli W, Beniston M. 1998. Climate change and its impacts on glaciers and permafrost in the Alps. Ambio: 258-265.

Hair J, Jr, Black W, Babin BJ, Anderson RE. 2014. Multivariate Data Analysis. New International Edition: Harlow, UK.

Hoelzle M, Haeberli W, Keller F. 1993. Application of BTSmeasurements for modelling mountain permafrost distribution. Proceedings, 6th International Conference on Permafrost. South China University Technology Press: Wushan; 272-277.

Hoelzle M, Wegmann M, Krummenacher B. 1999. Miniature temperature dataloggers for mapping and monitoring of permafrost in high mountain areas: first experience from the Swiss Alps. Permafrost and Periglacial Processes 10(2): 113-124.

Hollister R, Webber P, Bay C. 2005. Plant response to temperature in northern alaska: implications for predicting vegetation change. Ecology 86(6): 1562-1570.

Hülber K, Winkler M, Grabherr G. 2010. Intraseasonal climate and habitat-specific variability controls the flowering phenology of high alpine plant species. Functional Ecology 24(2): 245-252.

Ikeda A, Matsuoka N. 2002. Degradation of talus-derived rock glaciers in the Upper Engadin, Swiss Alps. Permafrost and Periglacial Processes 13(2): 145-161.

Ishikawa M. 2003. Thermal regimes at the snow-ground interface and their implications for permafrost investigation. Geomorphology 52(1): 105-120.

Kemppinen J, Niittynen P, Riihimäki H, Luoto M. 2018. Modelling soil moisture in a high-latitude landscape using LiDAR and soil data. Earth Surface Processes and Landforms 43(5): 1019-1031.

Körner C. 2003. Alpine plant life: functional plant ecology of high mountain ecosystems. 2nd ed. Springer-Verlag: Berlin Heidelberg.

Körner C, Paulsen J. 2004. A world-wide study of high altitude treeline temperatures. Journal of Biogeography 31(5): 713-732. 
Lambiel C, Bardou E, Delaloye R, Schuetz P, Schoeneich P. 2009. Extension spatiale du pergélisol dans les Alpes vaudoises; implication pour la dynamique sédimentaire locale. Bulletin de la Societe Vaudoise des Sciences Naturelles 91(4): 407-424.

Lambiel C, Pieracci K. 2008. Permafrost distribution in talus slopes located within the alpine periglacial belt, Swiss Alps. Permafrost and Periglacial Processes 19(3): 293-304.

Lane S, Borgeaud L, Vittoz P. 2016. Emergent geomorphic-vegetation interactions on a subalpine alluvial fan. Earth Surface Processes and Landforms 41(1): 72-86.

Lauber K, Wagner G, Gygax A. 2012. Flora Helvetica: flore illustrée de Suisse. Haupt: Bern.

Lavelle P, Lattaud C, Trigo D, Barois I. 1995. Mutualism and biodiversity in soils. In he Significance and Regulation of Soil Biodiversity, Lavelle DP, Lattaud C, Trigo D, Barois I, Collins H, Robertson G, Klug $M$ (eds). Springer: Dordrecht.

le Roux P, Luoto M. 2014. Earth surface processes drive the richness, composition and occurrence of plant species in an arctic-alpine environment. Journal of Vegetation Science 25(1): 45-54.

le Roux P, Virtanen R, Luoto M. 2013. Geomorphological disturbance is necessary for predicting fine-scale species distributions. Ecography 36(7): 800-808.

Malanson G, Bengtson L, Fagre D. 2012. Geomorphic Determinants of Species Composition of Alpine Tundra, Glacier National Park, U.S.A. Arctic, Antarctic, and Alpine Research 44(2): 197-209.

Mantel N. 1967. The detection of disease clustering and a generalized regression approach. Cancer Research 27(2): 209-220.

Matteodo M, Grand S, Sebag D, Rowley M, Vittoz P, Verrecchia E. 2018. Decoupling of topsoil and subsoil controls on organic matter dynamics in the Swiss Alps. Geoderma 330: 41-51.

Matthews J. 1992. The ecology of recently-deglaciated terrain: a geoecological approach to glacier forelands. Cambridge University Press: Cambridge.

Matthews J, Whittaker R. 1987. Vegetation Succession on the Storbreen Glacier Foreland, Jotunheimen, Norway: A Review. Arctic and Alpine Research 19(4): 385-395.

Meteoswiss. 2018. Bulletin climatologique année 2017. Genève.

Meteoswiss. 2019. Bulletin climatologique année 2018. Genève.

Moreau M, Mercier D, Laffly D, Roussel E. 2008. Impacts of recent paraglacial dynamics on plant colonization: A case study on Midtre Lovénbreen foreland, Spitsbergen $\left(79^{\circ} \mathrm{N}\right)$. Geomorphology 95(1): 48-60.

Niittynen P, Luoto M. 2018. The importance of snow in species distribution models of arctic vegetation. Ecography 41(6): 1024-1037.

Oksanen J, Kindt R, Legendre P, O'Hara B, Stevens MHH, Oksanen MJ, Suggests M. 2007. The vegan package. Community ecology package 10: 631-637.

Ozenda P. 1985. La végétation de la chaîne alpine dans l'espace montagnard européen. Masson: Paris.

PERMOS. 2019. Permafrost in Switzerland 2014/2015 to 2017/2018. In Glaciological Report (Permafrost) No. 16-19 of the Cryospheric Commission of the Swiss Academy of Sciences, Permos D, Noetzli J, Pellet C, Staub B (eds). Cryospheric Commission of the Swiss Academy of Sciences (SCNAT): Bern; 104.

Perret A, Martin S. 2015. Carte géomorphologique du vallon de Nant et étude de la marge proglaciaire du glacier des Martinets. Bulletin de la Murithienne 132: 69-82.

Pradervand J-N, Dubuis A, Pellissier L, Guisan A, Randin C. 2014. Very high resolution environmental predictors in species distribution models: Moving beyond topography? Progress in Physical Geography: Earth and Environment 38(1): 79-96.

Randin C, Vuissoz G, Liston G, Vittoz P, Guisan A. 2009. Introduction of Snow and Geomorphic Disturbance Variables into Predictive Models of Alpine Plant Distribution in the Western Swiss Alps. Arctic, Antarctic, and Alpine Research 41(3): 347-361.

Reisigl H, Keller R. 1987. Alpenpflanzen in Lebensraum: Alpine Rasen Schutt-und Felsvegetation. Vegetationsokologische informationen fur Studien: Exkursionen und Wanderungen.

Riihimäki H, Heiskanen J, Luoto M. 2017. The effect of topography on arctic-alpine aboveground biomass and NDVI patterns. International Journal of Applied Earth Observation and Geoinformation 56: 44-53.

Sandholt I, Rasmussen K, Andersen J. 2002. A simple interpretation of the surface temperature/vegetation index space for assessment of surface moisture status. Remote Sensing of Environment 79(2): 213-224.

Scherrer D, Körner C. 2011. Topographically controlled thermal-habitat differentiation buffers alpine plant diversity against climate warming. Journal of Biogeography 38(2): 406-416.

Schmid M-O, Gubler S, Fiddes J, Gruber S. 2012. Inferring snowpack ripening and melt-out from distributed measurements of nearsurface ground temperatures. The Cryosphere 6(5): 1127-1139.

Staub B, Marmy A, Hauck C, Hilbich C, Delaloye R. 2015. Ground temperature variations in a talus slope influenced by permafrost: a comparison of field observations and model simulations. Geologicae Helvetiae 70(1): 45-62.

Steinbauer MJ, Grytnes JA, Jurasinski G, Kulonen A, Lenoir J, Pauli $\mathrm{H}$, Rixen C, Winkler M, Bardy-Durchhalter M, Barni E, Bjorkman AD. 2018. Accelerated increase in plant species richness on mountain summits is linked to warming. Nature 556(7700): 231.

Stewart K, Grogan P, Coxson D, Siciliano S. 2014. Topography as a key factor driving atmospheric nitrogen exchanges in arctic terrestrial ecosystems. Soil Biology and Biochemistry 70: 96-112.

Stirling G, Wilsey B. 2001. Empirical Relationships between Species Richness, Evenness, and Proportional Diversity. The American Naturalist 158(3): 286-299.

Thornton JM, Mariethoz G, Brunner P. 2018. A 3D geological model of a structurally complex Alpine region as a basis for interdisciplinary research. Scientific Data 5: 180238.

van Tatenhove F, Dikau R. 1990. Past and Present Permafrost Distribution in the Turtmanntal, Wallis, Swiss Alps. Arctic and Alpine Research 22(3): 302-316.

Virtanen R, Luoto M, Rämä T, Mikkola K, Hjort J, Grytnes J-A, Birks H. 2010. Recent vegetation changes at the high-latitude tree line ecotone are controlled by geomorphological disturbance, productivity and diversity. Global Ecology and Biogeography 19(6): 810-821.

Vittoz P, Gmür P. 2009. Introduction aux Journées de la biodiversité dans le Vallon de Nant (Bex, Alpes vaudoises). Mémoire de la Société vaudoise des Sciences naturelles 23: 3-20.

Vittoz P, Randin C, Dutoit A, Bonnet F, Hegg O. 2009. Low impact of climate change on subalpine grasslands in the Swiss Northern Alps. Global Change Biology 157: 209-220.

Vonlanthen C, Bühler A, Veit H, Kammer P, Eugster W. 2006a. Alpine Plant Communities: A Statistical Assessment of Their Relation to Microclimatological, Pedological, Geomorphological, and Other Factors. Physical Geography 27(2): 137-154.

Vonlanthen C, Kammer P, Eugster W, Bühler A, Veit H. 2006b. Alpine vascular plant species richness: the importance of daily maximum temperature and pH. Plant Ecology 184(1): 13-25.

Westermann S, Boike J, Langer M, Schuler T, Etzelmüller B. 2011. Modeling the impact of wintertime rain events on the thermal regime of permafrost. The Cryosphere 5(4): 945-959.

Wildi O. 2017. Data analysis in vegetation ecology. Wiley-Blackwell: Chichester.

Wood S. 2017. Generalized Additive Models. Chapman and Hall/CRC: New York.

Yashiro E, Pinto-Figueroa E, Buri A, Spangenberg J, Adatte T, NiculitaHirzel $\mathrm{H}$ et al. 2018. Meta-scale mountain grassland observatories uncover commonalities as well as specific interactions among plant and non-rhizosphere soil bacterial communities. Scientific Reports 8(1): 5758.

Yee T, Mitchell N. 1991. Generalized additive models in plant ecology. Journal of Vegetation Science 2(5): 587-602.

\section{Supporting Information}

Additional supporting information may be found online in the Supporting Information section at the end of the article.

Figure S1. Longitudinal electrical resistivity tomography (ERT) profile realized the 16 August 2016 on Les Martinets rock glacier. The $x$-axis represents the longitudinal distance in meters from the profile starting point and the $y$-axis the elevation (ma.s.I.). The ERT profile was carried out with 48 electrodes and an inter-electrode spacing of $5 \mathrm{~m}$ from the upper lobe (UL) to the half part of the lower lobe (LL). The apparent 
resistivity were measured with the Syscal Pro Switch 96 (Iris Instruments). Salt-water saturated sponges were used to improve the contact between the electrodes and the ground because the surface was characterized by plurimetric blocks. Collected data were analyzed with the Prosys II software, in which the surface topography measured with dGPS was inserted. The inversion was carried out with the RES2DINV software. We choose least-square inversion and robust parameters, providing a good visualization of high resistivity contrasts (for further details in the methodology see Marescot, 2006; Hauck and Kneisel, 2008; Bosson et al., 2015). A high resistivity body (30 $\mathrm{k} \Omega \mathrm{m}$ on average with maximum of $300-500 \mathrm{k} \Omega \mathrm{m}$ ) is present in the upper part of the UL up to a depth of $30 \mathrm{~m}$. This can be interpreted as a permafrost layer. In the lower part of the $U \mathrm{~L}$, no permafrost is detected, considering low resistivity values $(<5 \mathrm{k} \Omega \mathrm{m})$. In the $\mathrm{LL}$, small patches of very high resistivities (300-500 $\mathrm{k} \Omega \mathrm{m})$ are interpreted as permafrost lenses. However, care have to be taken in the interpretation because of the relatively high error value (12.4\%). Bosson J, Deline P, Bodin X, Schoeneich P, Baron L, Gardent M, Lambiel C. 2015. The influence of ground ice distribution on geomorphic dynamics since the Little Ice Age in proglacial areas of two cirque glacier systems. Earth Surface Processes and Landforms 40 : 666-680. DOI: 10.1002/esp.3666. Hauck C, Kneisel C. 2008. Applied geophysics in periglacial environments. Cambridge University Press: Cambridge. Marescot L. 2006. Introduction à l'imagerie électrique du sous-sol. Bulletins des séances de la Société vaudoise des sciences naturelles 90: 23-40.

Table S1. List of plots with topographic information (elevation [meters], aspect [North $(-1)$ South $(+1)$ gradient] and slope [degrees]), landforms type, species cover (percentage of vascular plant cover - \%), and species richness (number of species per plot).

Figure S2. Left. Frequency of species cover [\%]. Center. Frequency of species richness $\left[\mathrm{n}^{\circ}\right.$ ]. Right. Frequency of evenness. Figure S3. Temperature distributions (period from 1 October 2016 to 30 September 2018) of iButtons, grouped according to plant composition. The box-plot delimit the $1^{\text {st }}$ and the $3^{\text {rd }}$ quantiles and the median (bold segment). The dotted line indicates the extremes and the small circle the outliers.

Figure S4. Examples of temperature evolution during one year. $\mathrm{RD}=$ basal-ripening data; $M D=$ melt-out date. iButton $\mathrm{n}^{\circ} 2$ is located at $2300 \mathrm{~m}$ a.s.I. in Les Martinets, in a debris area composed by ancient rock fall deposit and avalanche deposit. It does not have RD because of lack of ground freezing during the winter. iButton $n^{\circ} 63$ is situated in the upper part of the creeping talus slope in Col des Perris Blancs site, at $2426 \mathrm{~m}$ of elevation. In this case, both RD and MD were detected.

Figure S5. Correlation matrix between explanatory variables based on Spearman's rank correlation coefficient. Spearman correlation coefficient was set to $|\rho|>0.7$ as criterion to limit collinearity between the variables. MGST = Mean Annual Ground Surface Temperature; Tmin = minimum temperature; Tmax $=$ maximum temperature $; \mathrm{FDD}=$ Freezing Degree Day; GDD = Growing Degree Day; GSL = Growing season length; TVDI = Temperature Vegetation Dryness Index.

Figure S6a. Baseline GLM of species cover, with normal explanatory variables, family argument "Quasipoisson". Residuals vs Fitted, Normal Q-Q, Scale-Location and Residuals vs Leverage plots are shown.

Figure S6b. Baseline GLM of species cover, with quadratic explanatory variables, family argument "Quasipoisson". Residuals vs Fitted, Normal Q-Q, Scale-Location and Residuals vs Leverage plots are shown.

Figure S6c. Avanced GLM of species cover, with normal explanatory variables, family argument "Quasipoisson". Residuals vs Fitted, Normal Q-Q, Scale-Location and Residuals vs Leverage plots are shown.

Figure S6d. Avanced GLM of species cover, with quadratic explanatory variables, family argument "Quasipoisson". Residuals vs Fitted, Normal Q-Q, Scale-Location and Residuals vs Leverage plots are shown.

Figure S6e. Baseline GLM of species cover, with normal explanatory variables, family argument "Quasibinomial". Residuals vs Fitted, Normal Q-Q, Scale-Location and Residuals vs Leverage plots are shown.

Figure S6f. Baseline GLM of species cover, with quadratic explanatory variables, family argument "Quasibinomial". Residuals vs Fitted, Normal Q-Q, Scale-Location and Residuals vs Leverage plots are shown.

Figure S6g. Advanced GLM of species cover, with normal explanatory variables, family argument "Quasibinomial". Residuals vs Fitted, Normal Q-Q, Scale-Location and Residuals vs Leverage plots are shown.

Figure S6h. Advanced GLM of species cover, with quadratic explanatory variables, family argument "Quasibinomial". Residuals vs Fitted, Normal Q-Q, Scale-Location and Residuals vs Leverage plots are shown. 